\title{
Interactions entre virus ou entre virus et leurs satellites chez un hôte commun. II. - Interfé- rences positives: synergie, complémentation,
}

\section{assistance}

\author{
Georges MARCHOUX
}

I.N.R.A., Station de Pathologie végétale, Centre de Recherches d'Avignon, Domaine Saint Maurice, F 84140 Montfavet

Deux ou plusieurs virus, apparentés ou non, peuvent se multiplier ensemble dans une même plante et également dans une même cellule. Les interactions entre virus qui en résultent peuvent s'exprimer sur les formes variées allant de l'antagonisme (Marchoux, 1987) à la synergie. Dans les cas de synergic, les symptômes, la vitesse de multiplication et/ou la distribution d'un virus sont souvent augmentés en présence d'un autre virus.

Des interactions structurales nucléoprotéiques, telles que masquage génomique entre virus de morphologie distincte ou mélange phénotypique entre virus apparentés, sont mises en évidence dans des cellules co-infectées par 2 virus dont les cycles de réplication et la localisation se chevauchent.

La transmission de certains virus par pucerons, selon le mode persistant ou semi-persistant, n'est possible qu'en présence d'un virus assistant. Dans certains cas, cette assistance s'expliquerait par la constitution dans la plante doublement infectée de particules à génome masqué, c'est-à-dire par une protection de l'ARN dans la capside du virus assistant.

La transmission de certains virus par des aphides selon le mode non persistant nécessite la présence dans la plante d'un facteur assistant (FA) protéique codé par le génome viral. Les souches déficientes peuvent être transmises en présence de FA produits par une autre souche ou parfois par un autre virus.

Un mutant thermosensible, déficient pour la synthèse de la capside ou pour la fonction transport, peut être complémenté à température non permissive, soit par la souche normale tr, soit par un autre mutant ts déficient pour une autre fonction. Une plante à infection localisée pour un virus et dont la résistance est due au blocage de la fonction transport, peut être infectée de manière systémique par ce virus en présence de certains virus apparentés ou non eux-mêmes systémiques chez cet hôte.

Les virus à génome divisé ou multipartite requièrent pour se répliquer et être pathogènes, la coopération de plusieurs molécules d'ARN souvent encapsidées dans des nucléoprotéines distinctes. Il est possible de construire in vitro des recombinants par échange de molécules d'ARN génomiques équivalents entre 2 souches d'un même virus et parfois entre 2 virus appartenant au même groupe. Les avantages sélectifs présentés par les virus à génome divisé et l'importance des pseudo-recombinaisons naturelles sont discutés.

Les ARN satellites sont généralement de petite taille et sont complètement dépendants pour leur réplication d'un virus assistant spécifique. Les ARN satellites sont soit encapsidés avec l'acide nucléique de leur virus assistant (ou dans certains cas dans un virus satellite assistant), soit ils possèdent leur propre coque protéique. Dans de nombreux cas, la réplication de l'ARN satellite diminue la synthèse du virus assistant et atténue la gravité des symptômes. Ce type de parasitisme moléculaire entre virus et ARN satellites a fait naître l'espoir d'une utilisation agronomique pour lutter contre les virus économiquement graves et pour lesquels nous ne disposons pas d'autres solutions actuellement. S'appuyant sur les nouvelles possibilités de synthèse et d'intégration des ADN complémentaires dans le génome des plantes, de régénération des plantes transformées, plusieurs laboratoires ont engagé des recherches dans ce sens, en France et à l'étranger. Les types de molécules intégrées ou que l'on souhaite intégrer sont non seulement des ARN satellites, mais également le gène capside du virus ou des ARN anti-messagers. Plusieurs résultats encourageants ont déjà été obtenus.

Mots clés additionnels : Virus défectif, virus à génome divisé, pseudo-recombinaison, satellite, facteur assistant, protéine de transport, masquage génomique, mélange phénotypique.

Pairs of related and non-related viruses can often replicate together in a common host, indeed in individual cells. Interactions that occur as a consequence of mixed infections can be antagonistic (MARCHOUX, 1987) or synergistic. Symptoms, multiplication rate and/or distribution of one virus are often enhanced in the presence of another virus. Structural interactions such as : genomic masking between structurally dissimilar viruses and phenotypic mixing between structurally similar viruses can occur, so long as cells become doubly infected and 
replication cycles overlap. In the case of viruses transmitted in the persistent or semi-persistent mode and dependent on another virus, transmission by aphids is due to genomic masking during simultaneous replication of the two viruses in the plant. Virus assembly and spreading of infection (transport function) of ts-mutants can be complemented by tr-strains. A plant whose resistance to a virus is due to the blockage of the transport function can be infected systemically by this virus as a result of the complementation of transport with the helper virus, related or not. Some viruses transmitted by aphids in the non-persistent mode have been shown to be dependent on the presence of helper component (HC) produced by the virus. Deficient isolates can become aphidtransmissible when they are in m.ixed infection with a virus that does produce the HC. Infection of plant by viruses with a divided (multipartite) genome requires the presence of two or several parts to provide the complete genome essential for viral replication. Numerous pseudo-recombinants have been constructed in vitro by exchanging genomic RNA segments between pairs of strains of virus and sometimes also between pairs of related viruses. The advantages of divided genomes for survival value are discussed. Subgenomic RNAs of some viruses are partial transcripts of the genomic RNAs that, although not essential for initiating infection, are functional in virus synthesis (for example, subgenomic coat protein mRNA). There is a growing number of reports of RNA plant viruses that have particles associated with them containing satellite RNAs with no nucleotide sequence homology to either the viral or the host genomes. These satellites are completely dependent for their replication on the helper viruses with which they are associated. Satellite RNAs usually interfere with helper-virus synthesis and modify disease-symptom expression on the host plants. This type of «molecular parasitism » may be nature's device for regulating and containing the spread of plant viral diseases, and it is already being exploited by plant pathologists in attempts to control virus diseases biologically.

Additional key words : Defecive virus, divided genome, pseudo-recombination, satellite, helper component, virus transport protein, genomic masking, phenotypic mixing.

\section{INTRODUCTION}

Dans la nature ou en conditions expérimentales, deux ou plusieurs virus apparentés ou non sont susceptibles de se trouver ensemble dans une même plante, un même tissu, voire une même cellule. Les interactions qui résultent de cette co-infection nous apparaissent rarement neutres. On met le plus souvent en évidence soit un effet antagoniste d'un partenaire sur l'autre (MARCHOUX, 1987), soit un effet synergique favorable à l'un ou aux deux virus en présence. Les interactions positives, entre virus composant une infection mixte, ont été étudiées en comparaison avec les infections simples à différentes phases de l'infection virale. Les processus étudiés sont la nature et l'intensité des symptômes, la synthèse et la distribution du virus dans la plante, la gamme d'hôtes, l'aptitude à être transmis, les interactions structurales et génétiques entre composants protéiques et nucléiques spécifiques de chaque virus. De nombreux processus sont étroitement imbriqués et ces derniers sont utilisés pour tenter d'expliquer les phéromènes d'interactions biologiques souvent observés sur la plante entière.

Les échanges de composants structuraux nucléoprotéiques sont observés dans les cas d'interaction entre virus complets (génomes comportant toute l'information nécessaire à la survie de l'espèce) ou incomplets. Les complémentations génétiques concernent des virus mutants ou des composants viraux comportant une information génétique incomplète pour assurer leur multiplication et leur survie. Certains virus ou AR.N satellites sont eux, totalement dépendants pour leur réplication et leur conservation d'un virus assistant.

L'article présentera les différentes situations d'interactions entre virus, composants viraux ou satellites dans l'ordre croissant de la dépendance et réciproquement de l'assistance de l'un des éléments par l'autre, lors de leur interaction positive. Le plan suivi sera donc:

1. Interactions entre virus.

2. Complémentation de souches défectives d'un virus.
3. Interactions entre composants des virus à génome divisé.

4. Assistance des virus et ARN satellites.

Les 2 premiers chapitres apporteront des informations complémentaires sur les phénomènes de localisation tissulaire, diffusion de cellule à cellule, transport du virus dans la plante, gamme d'hôtes, aptitude à la transmission par les insectes.

Les 2 derniers privilégieront l'aspect moléculaire et nous renseigneront sur la spécificité de l'interaction, les mécanismes de réplication et les fonctions messagères des ARN viraux et satellites.

Certaines de ces interactions aboutissent à des compétitions ou des inhibitions défavorables aux virus. Les chercheurs tentent de les exploiter dans un objectif de lutte contre les virus des plantes cultivées.

\section{INTERACTIONS ENTRE VIRUS}

Lorsque 2 virus apparentés, ou non, infectent la même plante, le résultat de leur interaction est parfois visible au niveau des symptômes. Il peut y avoir interférence antagoniste et les symptômes observés sur la plante co-infectée par 2 virus seront plus faibles que ceux de chacune des infections uniques. En inoculations successives, la plante infectée par une première souche peut même devenir résistante à la seconde (MARCHOUX, 1987). L'infection simultanée peut, au contraire, avoir un effet synergique sur l'expression des symptômes, la gamme d'hôtes, la multiplication du virus, sa diffusion dans la plante et sa transmission par les insectes.

\section{A. Effets sur les symptômes induits par les 2 virus}

\section{Symptômes sur la plante infectée}

Il n'est pas rare que les symptômes induits par une double infection virale soient plus graves que ceux 
associés à chacun des virus. Ainsi, un des effets majeurs des infections simultanées par le PVX et le PVY chez beaucoup de variétés de pomme de terre et de tabac est que les symptômes sont beaucoup plus graves (mosaïque déformante ou frisolée) que ceux induits par le PVX ou le PVY seuls (marbrure ou mosaïque) (THOMSON, 1961a; STOUFFER \& ROSS, 1961 ; GOODMANN \& Ross, 1974b).

Parfois, l'interaction des 2 virus peut aboutir à l'apparition d'un syndrome nouveau; chez la tomate, par exemple, la plupart des souches de TMV produisent un symptôme de mosaïque; mais en combinaison avec le PVX, il y a développement d'un symptôme nécrotique (streak) qui peut entraîner la mort de la plante (ZACHOS, 1954). Ce résultat est obtenu même si le PVX est inoculé jusqu'à 14 jours après le TMV (Asselin, 1984).

Un phénomène similaire est observé chez la laitue doublement infectée par le LMV et le BWYV (ZINK \& DuFfus, 1972).

Certaines maladies, d'abord considérées comme liées à un seul virus, se sont révélées ensuite associées à 2 ou plusieurs virus (ou viroïdes) non apparentés. Parmi les exemples les plus récents, citons le Nanisme du vigna lié à l'infection mixte par le CMV et le BICMV (PIORibeiro et al., 1978), la Brûlure de la tomate: PVX + PVY (CLARK et al., 1980), la Nécrose du maïs : MCMV + MDMV (Uyemoto et al., 1981), la Nécrose de la pomme de terre : PVY + PSTV viroïde (SINGH, 1982). D'autres maladies complexes résultent de l'infection mixte par 2 virus dont l'association est rendue nécessaire pour assurer leur transmission par les insectes ( II F).

Signalons toutefois que la combinaison de 2 virus chez une même plante ne présente pas forcément un effet synergique sur les symptômes. Ainsi, chez le soja, les infections mixtes de SMV, TRSV, CCMV n'entraînent qu'un effet additif ou moins qu'additif sur le nanisme des plantes, le rendement en graines et leur composition en protéines et en huile (Demski \& Jellum, 1975).

Des résultats plus récents indiquent cependant que le rendement des sojas co-infectés par le SMV (Potyvirus) et le BPMV (Comovirus) est inférieur à celui des plantes à infection unique (CAlvert \& GHABrial, 1983).

\section{Altérations au niveau tissulaire et cellulaire}

Les virus qui se multiplient ensemble dans le cytoplasme, tels que TMV et TEV, forment des agrégats mixtes (FuJISAWA et al., 1967).

L'infection virale induit aussi le plus souvent la formation d'inclusions cellulaires, cristallines ou amorphes, spécifiques de l'espèce ou du groupe de virus. Les infections mixtes peuvent entrainer le développement d'inclusions nouvelles absentes avec les infections uniques. C'est ainsi que la co-infection CMV + TMV induit chez le tabac la formation d'inclusions intranucléaires particulières (HONDA \& MATSUI, 1968-1971).

Un autre exemple est fourni chez le haricot infecté par 2 virus morphologiquement distincts : BYMV (filamenteux) et BPMV ou CSMV (sphériques) mais qui se multiplient tous dans le cytoplasme. Avec les 2 combinaisons, on observe dans les cellules co-infectées, en plus des inclusions cytoplasmiques caractéristiques de chacun des virus, des arrangements de virions sphéri- ques le long des particules filamenteuses du BYMV. Seule la combinaison BYMV + CSMV entraîne la formation d'inclusions intranucléaires filamenteuses et sphériques qui sont absentes avec la combinaison BYMV + BPMV. Les tests sérologiques utilisant un immunsérum du CSMV conjugué à la ferritine ne révèlent aucune parenté sérologique entre les inclusions sphériques et la capside du CSMV (CARR \& KIM, 1982).

Un phénomène comparable est mis en évidence dans le cas des virus ayant une spécificité tissulaire. En effet, l'étude cytologique au microscope électronique des tissus du phloème d'avoine doublement infectés par 2 souches (MAV et RPV) de BYDV non reliées sérologiquement révèle la présence d'altérations non observées dans les tissus infectés par un seul variant. Des altérations similaires à celles de chacun des variants sont également présentes (GILL \& CHONG, 1981).

\section{B. Stimulation de la multiplication virale}

\section{Dans la plante}

Certaines co-infections de virus, surtout si elles sont décalées, entraînent une interférence antagoniste sur la multiplication de la souche challenger (MARCHOUX, 1987). Dans d'autres cas, l'un des virus peut atteindre des concentrations plus élevées que lorsqu'il est seul dans la plante.

Il peut s'agir de virus du parenchyme ainsi, chez le tabac et la tomate, le TMV en inoculation simultanée ou antérieure stimule la multiplication du PVX (GOODMAN \& Ross, 1974a). Chez le tabac, la multiplication du PVX est également stimulée d'un facteur 2 à 10 en présence du PVY (STOUfFer \& Ross, 1961 ; GoOdman \& Ross, 1974b). Citons aussi l'influence positive exercée par des virus de graminées: BSMV et BMV sur la multiplication du TMV chez l'orge (DodDs \& HAMILTON, 1972; HAMilton \& NichOLS, 1977).

Une interaction unilatérale est observée chez le soja où la concentration du BPMV est significativement plus élevée en présence du SMV alors que la concentration du SMV n'est pas modifiée par l'infection mixte (CALVERT \& GHABRIAL, 1983).

Un phénomène comparable est observé chez le concombre où la multiplication du CMV est significativement augmentée en présence du ZYMV que celui-ci soit apporté une à deux semaines avant ou après le CMV. La concentration du ZYMV est, en revanche, plus faible dans les plantes doublement infectées (POOLPOL \& INOUYE, 1986).

La multiplication de certains virus localisés dans le liber (Lutéovirus) peut également être stimulée par infection mixte. Chez l'avoine on note un effet synergique sur la multiplication virale exercé par la combinaison de certains variants de BYDV (AAPOLA \& ROCHOW, 1971 ; Halstead \& Gill, 1971).

Avec le Datura stramonium, les plantes doublement infectées par le PLRV et le PVX contiennent davantage de PLRV que les plantes infectées par ce seul virus (AtABEKov et al., 1984). Chez Nicotiana clevelandii la multiplication du PLRV est augmentée 8 fois en présence du PVY, alors que la concentration de ce dernier est inchangée. Dans les mêmes conditions la 
concentration du PLRV n'est pas augmentée dans les plants de pomme de terre co-infectés avec le PVY (BARKER, 1987).

Dans tous ces exemples, l'étendue de l'effet synergique souvent unilatéral est beaucoup influencé par les souches de virus, le temps ménagé entre les deux inoculations et le génotype de l'hôte. Ainsi, chez un cultivar de pomme de terre sensible, on observe une augmentation de la synthèse du PVX en présence du PVY; au contraire, chez le cultivar résistant la multiplication du PVX reste presque complètement inhibée bien qu'un effet synergique soit observé sur l'intensité du nanisme. Cet exemple montre que l'effet synergique sur les symptômes n'est pas forcément lié à une augmentation de la multiplication du ou des virus en préserice, mais que le génome de la plante a une influence déterminante (MAYEE \& SARKAR, 1982). La réponse synergique du vigna au nanisme nécrotique (CMV + BICMV) est sous la dépendance d'un gène incomplètement dominant (PIO-Ribeiro et al., 1980).

\section{Co-infections de protoplastes}

La culture des cellules végétales isolées est une technique intéressante pour étudier dans un système synchrone, l'effet des co-infections simultanées ou décalées par 2 virus, même si le comportement des protoplastes ne correspond pas aux réactions des tissus in vivo. Les progrès enregistrés dans la sensibilité des méthodes de détection et d'analyses biochimiques ont contribuè à une meilleure connaissance des cinétiques de multiplication des virus en présence.

Dans des protoplastes de mésophylle du tabac, doublement infectés in vitro par le CMV et le TMV, 70 à 80 p. 100 des cellules sont le siège d'une double infection sans effet antagoniste ni synergique apparent (OTSUKI \& TAKEBE, 1978).

Jusqu'à 95 p. 100 d'infections mixtes ont été obtenues dans les protoplastes de Nicotiana benthamiana avec un Nepovirus (RRSV) et un Tobravirus (TRV) (BARKER \& HARRISON, 1977). Cette double infection conduit à une redistribution des particules sphériques du RRSV qui s'agrègent sur les bâtonnets du TRV eux-mêmes attachés aux mitochondries. Ce phénomène, spécifique de la souche du TRV, serait lié à une interaction hydrophobique entre virions (HARRISON et al., 1977).

Une double infection des protoplastes peut être également observée lorsque 2 souches d'un même virus sont mises en présence. Lors de l'inoculation simultanée de 2 souches de TMV à des protoplastes de tabac, une infection double concerne 80 p. 100 des cellules dans lesquelles, plus de 90 p. 100 des particules virales contiennent des antigènes des 2 souches (mélange phénotypique). L'inoculation séquentielle mais quasi immédiate des 2 souches conduit à la double infection d'environ 50 p. 100 des protoplastes (OTSUKI \& TAKEBE, 1978). Toutefois le fait que 2 souches puissent infecter un même protoplaste n'implique pas que l'infection par une souche n'est pas affectée par l'autre. $\mathrm{Au}$ contraire, les 2 souches de TMV entrent en compétition durant la réplication et certains protoplastes infectés par la première souche deviennent réfractaires à l'infection par la souche challenger (MARCHOUX, 1987).

\section{Effets sur la diffusion du virus dans la plante}

\section{Virus du parenchyme}

La diffusion systémique d'un virus qui normalement reste localisé aux feuilles inoculées, est parfois rendue possible par la présence d'un second virus qui lui, se généralise.

Ainsi, chez Nicotiana sylvestris, la souche aucuba du TMV produit des lésions locales nécrotiques restreintes à quelques feuilles. Or les plantes infectées par un mélange de cette souche et de la souche commune (mosaïque systémique) présentent des symptômes systémiques de mosaïue et des taches jaunes.

La souche aucuba a été isolée dans ces taches. La présence de la souche commune facilite done le mouvement de la souche aucuba à l'intérieur de la plante.

Un autre exemple est celui du PVX qui reste localisé à $31{ }^{\circ} \mathrm{C}$ chez le tabac. Si les plantes sont également infectées par un virus non apparenté : PVY, TMV ou CMV, alors le PVX se généralise dans la plante. Le phénomène est lié à une augmentation de la multiplication du PVX d'un facteur 2 dans les feuilles inoculées quel que soit l'ordre d'inoculation et d'un facteur 10 dans les feuilles "systémiques" si l'infection est simultanée ou si le PVY est inoculé après le PVX. Les études ultrastructurales par marquage avec des anticorps fluorescents montrent que les 2 virus se sont multipliés dans les mêmes cellules. L'augmentation de la quantité de virions du PVX est liée à un plus grand nombre de cellules infectées et non à une synthèse accrue par cellule. La présence du PVY faciliterait donc le mouvement du PVX de cellule à cellule dans la feuille inoculée (Stouffer \& Ross, 1961 ; Close, 1964).

Chez l'orge, le TMV ne diffuse et ne se multiplie de façon systémique qu'en présence du BSMV ou du BMV (HAMILTON \& DODDS, 1970 ; HAMILTON \& NiCHOLS, 1977). Ce phénomène pourrait être lié à la transencapsidation de l'ARN du TMV par la protéine capsidiale du BSMV (DODDS \& HAMILTON, 1974). Comme nous le verrons ensuite, l'activité d'une protéine de transport codée par un virus assistant peut faciliter la diffusion d'un virus incapable d'effectuer cette fonction (§ III B).

\section{Virus du phloème}

Les Luteovirus et les Geminivirus sont inféodés aux tissus phloémiens de la plante. Ils sont pourtant aptes à se multiplier dans les protoplastes mésophylliens. Leur localisation tissulaire résulterait donc de leur incapacité à passer du phloème aux autres tissus. Or, chez Datura stramonium, le PLRV normalement localisé dans les tissus libériens peut s'accumuler dans les cellules parenchymateuses lorsque la plante est également infectée par le PVX (ATABEKov et al., 1984). Ces résultats ont été confirmés chez Nicotiana clevelandii où le pourcentage de protoplastes mésophylliens, infectés par le PLRV passe de 0,2 p. 100 (infection unique) à 1,4 p. 100 lorsque les feuilles sont doublement infectées avec le PVY. Avec la pomme de terre, ce pourcentage demeure nul dans les 2 cas (BARKER, 1987).

Des observations similaires ont été faites avec un Geminivirus. Les effets cytopathologiques exercés par le 
BGMV sont restreints au phloème quand il est seul et s'étendent aux autres tissus quand il est associé au TMV (CARR \& KIM, 1983).

Chez l'avoine infectée simultanément par 2 souches de BYDV, non reliées sérologiquement (MAV et RPV), on observe que les tissus du xylème normalement insensibles à chacune des souches peuvent être envahis par le virus (GILL \& CHONG, 1981).

Dans tous ces cas, la spécificité tissulaire du virus est contournée. Comme pour l'assistance des virus de parenchyme entre eux, l'hypothèse d'une complémentation de la fonction transport du virus assisté par le virus assistant est avancée (§ III B).

\section{Modification de la gamme d'hôtes}

Comme la majorité des pathogènes et particulièrement comme les parasites stricts, les virus ont une gamme d'hôte relativement spécifique. Les phénomènes d'interférence entre virus suggèrent que l'interaction entre des motifs structuraux de la capside virale et les récepteurs cellulaires constitue le stade crucial de l'inoculation virale. Ce phénomène peut limiter la gamme d'hôtes d'un virus dans les tous premiers stades de l'interaction virus-cellule (MARCHOUX, 1987).

La contribution de la protéine capside, dans le contrôle de la spécificité d'hôtes, a été étudiée par réassociation in vitro des protéines et des ARN provenant de virus différents. Dans le cas du BMV, l'encapsidation de l'ARN dans la protéine du TMV le rend inapte à l'infection de l'orge. En revanche, les « hybrides » formés de l'ARN du TMV ou du PVX encapsidés dans la protéine du CV4 conservent leur capacité d'infecter différentes espèces pourtant résistantes à ce virus. Enfin, dans aucun cas il n'est montré qu'une capside hétérologue soit capable d'élargir la gamme d'hôtes de l'ARN encapsidé (ATABEKOV, 1975).

Lorsque le virus ne se réplique que dans les premières cellules inoculées et ne peut envahir toute la plante, on est en situation d'infection subliminaire et la plante peut être considérée comme «non-hôte » (WYATT \& KUHN, 1979; Sulzinski \& Zaitlin, 1982). On sait qu'un certain nombre de virus sont capables de se multiplier dans des protoplastes d'espèces non-hôtes ou de variétés résistantes. Par exemple, dans les protoplastes de tomates résistantes au TMV, le gène $\mathrm{Tm} 2$ (résistance par hypersensibilité) ne s'exprime pas alors que le gène Tm 1 (résistance à la multiplication) s'exprime (FRASER \& Loughlin, 1980). Or des tomates Tml préinfectées par le PVX demeurent résistantes alors que les variétés Tm2 préinfectées par le même virus deviennent sensibles au TMV. L'accumulation du TMV deviendrait possible grâce à l'activité d'un facteur de transport codé par le PVX qui permettrait la diffusion du TMV dans toute la plante. On peut penser que le gène $\mathrm{Tm} 2$ confère la résistance par blocage du mouvement de cellule à cellule. La fonction transport du TMV (Cf. § III B) ne pourrait s'exprimer en présence de ce gène. En revanche, le fait que les tomates $\operatorname{Tm} 2$ deviennent sensibles après infection par le PVX indiquerait que leur physiologie pourrait être modifiée et permette ainsi la diffusion du TMV. Selon cette théorie, une plante non-hôte dont la résistance à un virus est due au blocage de la fonction transport peut être infectée de façon systémique par complémentation de cette fonction par un virus assistant (TALIANSKY et al., 1982c).
Les mêmes auteurs ont également montré que le BMV normalement non pathogène sur tomate et haricot, le devient quand il est assisté respectivement par le TMV (souche systémique) et le DEMV. Un phénomène comparable est observé dans le cas du TMV assisté du BSMV chez le blé (TAliANSKy et al., 1982a). Plus récemment, WEBER et al. (1985) ont observé que le CGMMV qui normalement n'infecte pas le chénopode, se généralise dans la plante, sans produire de symptôme, en présence du CLSV.

Les mécanismes qui entraînent la modification d'une gamme d'hôtes en présence d'un autre virus ne sont pas connus. En plus de l'assistance pour le transport, ce phénomène pourrait s'expliquer notamment par la dérégulation des populations d'ARN de transfert et des inhibiteurs actifs sur la maturation des produits de traduction.

\section{E. Modifications des structures nucléoprotéiques}

L'assemblage de l'acide nucléique et des protéines capsides en particules virales apparaît comme un mécanisme relativement spécifique puisqu'il n'y a généralement pas encapsidation d'acide nucléique étranger. On a cependant observé dans les préparations de TMV jusqu'à 2,5 p. 100 de pseudo-virions contenant de l'ARN de la plante (SIEGEL, 1971).

Dans les cellules doublement infectées, par 2 virus A et $B$, il y a 2 pools de composants présents. Si le phénomène d'encapsidation n'est pas spécifique, il peut y avoir production de particules construites avec des éléments structuraux hétérologues. On peut observer dans la descendance des particules formées du génome $\mathrm{du}$ virus $\mathrm{A}$ et de la capside $\mathrm{B}$. Ce phénomène de transencapsidation est appelé masquage génotypique total ou partiel. Dans ce dernier cas le mélange phénotypique observé est constitué de capsides hétérogènes en proportions très variables ou non de sous-unités protéiques de A et de B.

L'effet de différents facteurs jouant sur le rapport de concentration entre les 2 virus et les réassemblages hétérologues a été étudié in vitro et dépend beaucoup de la paire de virus en présence (DODDS \& HAMILTON, 1976). In vivo, le niveau des interactions dépend aussi du rapport des composants. La composition des pools ARN et sous-unités protéiques est nettement influencée par l'hôte et certains paramètres: les conditions de croissance de la plante, le rapport des vitesses de. multiplication des virus, le délai ménagé entre l'inoculation des 2 virus et la durée de l'infection. L'ordre d'inoculation a une grande importance; ainsi, lorsque l'un des virus a une vitesse de multiplication plus rapide, son inoculation en second favorise l'apparition $\mathrm{du}$ phénomène de mélange phénotypique. L'explication serait que les phases de maturation de chacun des virus coïncideraient davantage.

\section{Masquage génotypique}

Le premier exemple de masquage génotypique résultant de l'infection mixte avec 2 souches a été rapporté chez les Luteovirus. Les souches A et B de BYDV diffèrent par une spécificité de vection de certaines espèces de pucerons et par leurs propriétés sérologiques. 
Quand la souche A transmissible par une espèce de puceron est multipliée chez l'avoine en présence de la souche B non transmissible, celle-ci est transmise par les pucerons. Il a été montré en sérologie que cette transmission pourrait s'expliquer par le fait que l'ARN de la souche B a été partiellement ou totalement encapsidé par la protéine manteau de la souche A (RocHow, 1970).

Des masquages génotypiques peuvent également survenir entre virus non apparentés, de même morphologie mais de taille différente. Chez l'orge, une partie de l'ARN du TMV (Tobamovirus) est encapsidée par la protéine du BSMV (Hordéivirus). C'est dans les parties de la plante où la synthèse de l'ARN du TMV est la pius grande, que ce phénomène est le plus fréquent (DoDDS \& HAMILTON, 1974).

Egalement chez l'orge doublement infectée par 2 virus de morphologie différente, on met en évidence qu'une petite partie de l'ARN du BSMV (bâtonnets) est protégée par la capside du BMV (sphérique). La nonréciprocité du phénomène s'expliquerait par une forte synthèse de l'ARN et par conséquent de la capside du BMV par rapport à celle du BSMV (PETERSON \& BRAKKE, 1973). Citons aussi le cas du viroïde PSTV qui peut être encapsidé in vivo par le VTMV (FRANCKI et al., 1986).

Il faut remarquer qu'un certain nombre d'infections mixtes ne conduisent pas à des structures nucléoprotéiques hétérologues apparentes (TMV + PVX ou PVX + PVY, KaSSANIS \& CONTI, 1971 ; GOODMAN \& ROSS, $1974 c$; TMV et CMV ou TMV et TNV, Kassanis \& ConTI, 1971). L'accroissement de la diffusion de l'un de ces virus en présence d'un second, présenté au § II Cl, ne semble donc pas résulter dans ces cas-là de la constitution de particules mixtes.

In vitro, certaines associations acide nucléiqueprotéine capsidiale peuvent, notamment en absence du composant homologue, aboutir à des encapsidations hétérologues en particulier pour des couples chez lesquels le phénomène n'est pas observé in vivo (GOODMAN \& Ross, 1974b). Des expériences de compétition in vitro entre ARN et protéines capsidiales homologues et hétérologues permettaient de définir la probabilité d'existence de nucléoprotéines à génorne partiellement ou complètement masqué in vivo. Dans la cellule, les sites de multiplication et de maturation de 2 virus devront probablement être communs ou très proches pour que des nucléoprotéines mixtes apparaissent.

D'autres exemples de génomes partiellement ou totalement masqués seront abordés à propos des souches défectives pour la capside, des virus à génome divisé et des satellites de virus.

\section{Mélanges phénotypiques ou chimères capsidiques}

La formation de particules à capside chimérique n'est connue qu'entre 2 virus apparentés. Le phénotype de ces particules apparaîtra selon différents critères (sérologie, migration électrophorétique) de façons plus ou moins intermédiaires entre ceux des 2 virus parentaux.

L'inoculation simultanée ou décalée de 2 souches de TMV, soit sur des feuilles de tabac, soit dans des protoplastes du mésophylle, aboutit fréquemment à des infections mixtes montrant des mélanges phénotypiques. Les tests sérologiques, utilisant chacun des antisérums spécifiques, mettent en évidence la formation de particules à capside hétérogène qui réagissent avec l'un et l'autre des anti-sérums (SKOTNICKI et al., 1976-1977; OTSUKI \& TAKEBE, 1978).

L'immuno-électromicroscopie s'est révélée aussi une méthode de choix pour mettre en évidence l'encapsidation hétérogène de 2 Potyvirus de Solanacées infectant le piment (Delecolle et al., 1984).

\section{F. Assistance à la vection}

Dans les conditions naturelles d'infections mixtes chacun des virus est probablement acquis et transmis de façon indépendante. Cependant, des exemples de plus en plus nombreux montrent que la transmission de l'un des virus dépend de la présence d'un autre virus ou de son produit. Des exemples de transmission dépendante sont connus chez les virus transmis selon les modes non persistant, semi-persistant et persistant ou circulant.

\section{Virus non persistants}

L'assistance à la vection, entre virus différents ou entre souches d'un même virus, n'est connue, jusque-là, qu'en présence d'un Potyvirus. Chez les virus de ce groupe, une protéine ou facteur assistant (FA) produit dans la plante infectée, est nécessaire pour que le virus soit transmissible par les pucerons. Certains isolats perdent la faculté de produire le FA et ne peuvent plus être transmis de façon indépendante par les pucerons. Il s'agit donc de souches déficientes dont les possibilités de complémentation seront examinées plus en détail au $\S$ III C.

\section{Virus semi-persistants}

Un exemple de dépendance des virus de ce groupe est connu chez les Ombellifères. La transmission selon le mode semi-persistant du PYFV par le puceron, Cavariella aegopodii nécessite la présence de l'AYV. Le PYFV peut être acquis soit simultanément avec l'AYV dans une plante co-infectée soit postérieurement à l'acquisition du virus assistant. En préparation purifiée, le PYFV est acquis sur membrane uniquement si les pucerons sont déjà porteurs de l'AYV (ELNAGAR \& Murant, 1976a, b). Un autre clostérovirus des Ombellifères, l'HLV est dépendant pour sa transmission par C. aegopodii d'un virus assistant présent naturellement chez Heracleum sphondylium. Par contre, l'AYV ne peut assister la transmission de l'HLV (BEM \& MURANT, 1980).

Les mécanismes d'assistance de la transmission des virus semi-persistants ne sont pas totalement connus ; ils semblent reposer pour l'HLV sur une action structurelle de la protéine capsidiale du virus assistant.

\section{Virus persistants}

Avec ce groupe de virus, virus assistant et virus dépendant doivent être acquis simultanément pour réussir la transmission de ce dernier. 
Le premier exemple décrit de transmission dépendante a été le BYDV. La souche MAV transmise par Macrosiphum avenae (et d'autres espèces de pucerons) n'est pas transmissible par Rhopalisiphum padi alors que le RPV transmis par R.padi (et d'autres espèces de pucerons) n'est pas transmis par $M$. avenae. Le résultat de l'infection mixte MAV + RPV est que la souche de MAV devient transmissible par $R$. padi (Rochow, 1970, 1975). Des observations similaires ont été étendues à d'autres isolats de BYDV (Rochow \& GILL, 1978).

Un autre groupe de virus persistants, dépendants pour leur transmission, est constitué par les associations de 2 virus appartenant à des taxons très éloignés, différents par leurs propriétés physiques, la spécificité tissulaire, la transmission par les insectes. Les exemples décrits concernent des virus dépendants transmissibles mécaniquement mais dont la transmission aphidienne nécessite la présence d'un virus assistant qui appartient généralement au groupe des Lutéovirus. La maladie complexe du tabac "Tobacco rosette" est formée de l'association du TMotV assisté du "Tobacco vein distorting virus " transmis par Myzus persicae selon le mode persistant (SMITH, 1946).

Une grave maladie des carottes, répandue dans le monde entier, appelée "Carrot mottley dwarf » résulte de l'infection par le CMotV (transmissible mécaniquement) assisté pour sa transmission aphidienne (Cavariella aegopodii) par le CRLV (non transmissible mécaniquement) (Watson \& SerJeant, 1964). Deux autres complexes de ce type ont été décrits en Afrique sur arachide et tabac, ce sont les "Groundnut rosette » (Hull \& AdAms, 1968) et « Tobacco yellow vein disease " (ADAMS \& HULL, 1972).

Enfin la maladie «Lettuce speckles» présente en Californie sur laitue, betterave et épinard est liée à l'association du virus du même nom et du BWYV. Le premier est le virus dépendant, le second, le virus assistant de la transmission par Myzus persicae (FALK et al., 1979).

La maladie du haricot "Bean yellow vein-banding" décrite en Angleterre, est un autre exemple intéressant. Elle est due au virus du même nom qui est dépendant pour sa transmission par Acyrthosiphon pisum du PEMV, virus transmis seul sous le mode persistant mais qui n'est pas un Lutéovirus. Cependant, le Pea (bean) leaf roll, membre de ce groupe, est un virus assistant efficace (COCKBAIN, 1978).

L'étude des mécanismes de transmission des virus par les pucerons selon le mode persistant a mis en évidence le rôle primordial et spécifique de la protéine capsidiale.

Nous avons vu que le phénomène d'assistance, entre isolats du BYDV s'expliquait par un mécanisme de transencapsidation partielle ou totale (RocHOw, 1970). Il semble que ces mêmes mécanismes d'encapsidation hétérologue et de réciprocité entre les sites de reconnaissance sur la protéine capsidiale et les membranes des glandes salivaires pourraient intervenir dans la transmission dépendante des complexes de virus persislants (Adams \& Hull, 1972; Elnagar \& Murant, 1978 ; FALK et al., 1979; MURANT et al., 1985).

Le phénomène d'assistance pour la vection a des conséquences vitales évidentes pour le virus ou la souche dépendante. Cette réussite pourrait en revanche avoir des conséquences négatives sur la dissémination du virus assistant dont le FA ou les protéines capsidiales sont en quelque sorte détournées.

\section{G. Discussion}

Les infections mixtes d'une plante par 2 ou plusieurs virus sont fréquentes dans la nature et grâce aux progrès des méthodes de caractérisation, l'étude étiologique de nouvelles ou même d'anciennes maladies, révèle parfois la présence d'un complexe viral. Les infections mixtes peuvent être désavantageuses pour la plante lorsque l'association des 2 virus est synergique. Par des mécanismes encore inconnus, la réplication, la diffusion des virus et l'effet pathogène sur la plante sont alors plus grands que la somme des infections uniques. Les infections complexes peuvent avoir un effet quantitatif sur le développement de l'épidémie puisque les probabilités de transmission, notamment par les insectes vecteurs, peuvent être augmentées.

L'étude des interactions structurales entre virus infectant la même plante a montré que l'ARN de l'un peut être encapsidé totalement ou partiellement dans la protéine capsidiale de l'autre. La constitution de cette particule mixte a parfois pour conséquences de permettre à l'un des virus d'infecter une espèce non-hôte, de diffuser dans des tissus nouveaux ou d'être transmis par une espèce d'insecte normalement non vectrice pour lui. Il s'agit notamment de certains virus transmis selon le mode persistant ou semi-persistant, et l'étude de ces complexes viraux a permis de confirmer le rôle primordial de la protéine capsidiale dans la vection spécifique de ces virus par les pucerons. Au contraire, la transmission de certains groupes de virus non persistants est sous la dépendance d'un facteur assistant dont nous parlerons au $\S$ suivant.

L'étude des interactions structurales entre virus présente aussi un intérêt taxonomique puisque nous avons vu que seuls les virus apparentés, ou les souches d'un même virus, sont en mesure de produire des capsides hétérogènes ou des mélanges phénotypiques. On peut imaginer que les degrés de parenté entre virus puissent être estimés par des mesures quantitatives du phénomène. Par exemple, en immunoélectromicroscopie, on noterait la proportion de particules hétérogènes dans les extraits de plantes doublement infectées dans des conditions contrôlées.

Les études histologiques et cytologiques des infections mixtes apportent des informations sur les mécanismes de restriction tissulaire et sur les sites de synthèse et d'assemblage des virus. Nous avons vu également un exemple où les études ultrastructurales de complexes de virus peuvent être utilisées pour la discrimination de virus apparentés.

Les interactions structurales entre virus rapportées ici ne concernent que des échanges ou des constructions momentanées de protéines capsidiales; elles ne sont donc pas héréditaires. Même dans les cas de masquage génomique, le génome n'est que physiquement caché, il conserve, inchangées, toutes ses propriétés héréditaires essentielles.

\section{COMPLÉMENTATION DE SOUCHES DÉFECTIVES D'UN VIRUS}

Les virus sont défectifs quand ils ont perdu l'une de leurs fonctions essentielles pour leur conservation, 
autrement dit quand l'un de leurs gènes ne permet pas la synthèse de la protéine normalement codée. Des virus défectifs existent dans la nature, ils doivent leur survie à un virus assistant dont ils sont totalement dépendants $(\S \mathrm{V})$. Dans ce chapitre, nous parlerons des mutants défectifs artificiels, généralement obtenus après traitement par l'acide nitreux, et de certains variants naturels qui ont perdu la faculté d'être transmis par leur vecteur.

Leur défectivité peut être conditionnelle : ainsi les mutants thermosensibles (ts) ont un comportement «sauvage» à température permissive. La fonction défective d'un mutant peut être également compensée en présence d'une souche sauvage (complémentation simple) ou d'un mutant défectif pour une autre fonction (complémentation double ou réciproque). Quelles sont les fonctions concernées par ce type d'interaction génétique entre virus?

\section{A. Encapsidation}

De nombreux mutants artificiels du TMV ne forment pas de virions complets à température élevée, soit que la protéine capsidiale n'est pas synthétisée, soit que celle-ci n'a pas de configuration native à température supraoptimale. Si, en plus du mutant ts, les plantes sont co-infectées avec une souche sauvage, même éloignée sérologiquement, alors une partie des nucléoprotéines formées sont constituées de l'ARN du mutant ts et de la capside de la souche normale (SARKAR, 1969; ATABEKOV et al., 1970 ; KASSANIS \& BASTOW, 1971 ; KASSANIS \& ConTI, 1971).

On retrouve donc le phénomène de masquage du génome rencontré dans les interactions entre virus complets. Ici, la formation des particules à génome masqué résulte du fait que 2 sortes d'ARN sont en présence d'une seule sorte de protéine capsidiale fonctionnelle.

L'infection mixte de 2 souches normales de TMV conduit beaucoup plus rarement à la formation de particules ARN-capside hétérologues (ATABEKOVA et al., 1975).

La souche sauvage se comporte en virus assistant puisqu'elle rend stable les mutants structurellement défectifs qui, sans son concours, seraient sous forme d'ARN libre très instable.

L'interaction entre mutant ts et souche sauvage a été étudiée avec le modèle CCMV/protoplastes de Vigna. A $35^{\circ} \mathrm{C}$ lorsqu'il est seul, le mutant ts se réplique activement mais il n'y a pas production de protéine capsidiale. En présence de la souche sauvage, il y a formation dans 90 p. 100 des cas de virions formés de l'ARN ts protégé par la capside de type sauvage. On sait que le CCMV est un virus à génome divisé (cf. $§$ IV) dont l'ARN-3 code pour la synthèse de la capside (BANCROFT \& LANE, 1973). La conservation du caractère ts, dans la descendance des virions formés dans les protoplastes cultivés à $35^{\circ} \mathrm{C}$ (mais également à $25^{\circ} \mathrm{C}$ ), résulte probablement du fait que l'ARN-3 ts est davantage encapsidé que l'ARN3 de la souche sauvage (DAwsOn et al., 1975; DAwSON \& WATTS, 1979).

La survie du CCMV-ts à $35^{\circ} \mathrm{C}$ ne peut être assurée par le BMV virus du même groupe dont les ARN sont pourtant aptes à former un pseudo-recombinant in vitro. Cette situation résulterait de la dominance du
BMV qui empêche la synthèse des ARN infectieux du CCMV même si celui-ci est une souche normale et que l'on se place à $25^{\circ} \mathrm{C}$. On ne met pas non plus en évidence une encapsidation de l'ARN du BMV dans la protéine manteau du CCMV (WATTS \& DAWSON, 1980 ; SAKAI et al., 1983).

Signalons aussi que la complémentation des mutants ts n'est pas toujours possible. Ainsi, le mutant Ni 2519 du TMV ne peut être complémenté à température non permissive par la souche sauvage qui apporte pourtant des sous-unités capsidiales fonctionnelles. Chez ce mutant, la non-formation de particules ne dépendrait pas d'une protéine capsidiale déficiente mais probablement plutôt des propriétés structurelles des molécules d'ARN elles-mêmes (TALIANSKY et al., 1982a).

\section{B. Diffusion et transport du virus}

Certains auteurs, dont ceux mentionnés ci-après, pensent que la diffusion de cellule à cellule et le transport à plus grande distance représentent une ou des fonctions codées par le virus.

Par des expériences de transfert thermique, il a été montré que le mutant Ni 2519 du TMV est également déficient pour cette fonction à température non permissive. Il peut être complémenté par une souche normale mais le fait qu'il soit défectif pour 2 fonctions rend l'interprétation des résultats délicats (TALIANSKY et al., 1982a). Le mutant LS1 du même virus, lui, se multiplie normalement, à température non permissive, dans les cellules mais il ne diffuse pas dans les tissus voisins (Nishiguchi et al., 1978). En revanche, si la plante est préinfectée par une souche thermorésistante (tr), on met en évidence par immunofluorescence un mouvement de LS1 de cellules à cellules dans les tissus de tabac. Le résultat est étendu au niveau du passage dans les feuilles supérieures. LS1 peut migrer dans les vaisseaux conducteurs mais il y reste confiné s'il est seul. Si les feuilles supérieures ont été préinfectées par une souche tr, il y a pénétration de LS1 dans les tissus du mésophylle. Plus étonnant est le fait qu'un virus systémique appartenant à un autre groupe (Potexvirus) comme le PVX peut également «assister » le mutant LS1 (TALIANSKY et al., $1982 b)$.

Pour expliquer ces phénomènes, ces auteurs ont avancé, 2 groupes d'hypothèses :

1. Dans la plante, les membranes et parois cellulaires constituent des barrières interférant avec le mouvement du virus de cellule à cellule. Un virus hôte de cette plante serait capable de modifier certaines structures cellulaires, par exemple en augmentant la taille et ou le nombre de plasmodesmes fonctionnels entre cellules infectées et cellules saines voisines. Ces modifications ne seraient utilisables que par certains virus ou groupes de virus (Shalla et al., 1982 ; Sulzinski \& Zaitlin, 1982).

2. Il y aurait formation d'un complexe de l'ARN du mutant ts avec une protéine codée par la souche tr qui permettrait le mouvement du virus de cellule à cellule.

On sait que les capsides de la souche sauvage $\mathrm{L}$ et du mutant LS1 sont identiques. L'analyse comparée des produits de traduction in vitro ne montre pas de différences au niveau des peptides 130 et $165 \mathrm{kd}$. En revan- 
che la protéine $30 \mathrm{kd}$ du mutant ts révèle une substitution (proline $\rightarrow$ sérine) par rapport à la protéine synthétisée par la souche tr. Cette petite protéine qui n'est pas impliquée dans la réplication pourrait donc jouer un rôle dans le passage du virus de cellule à cellule (LEONARD \& ZAITLIN, 1982; OHNO et al., 1983).

Il a été mis en évidence dans les cellules infectées par le TMV, des nucléoprotéines spécifiques du virus (vRNP) différentes des particules matures par la structure, la densité et la sensibilité à la ribonucléase (Dorokhov et al., 1983).

Ces auteurs ont étudié 2 groupes de mutants afin de montrer s'il y a corrélation entre la formation des vRNP (constituées des ARN génomiques et subgénomiques, de la protéine $30 \mathrm{kd}$ et de la protéine capsidiale sous une forme particulière) et la diffusion du virus dans la plante infectée. Les mutants du premier groupe tel que Ni 118 comportent une mutation ts sur le gène-capside mais sont capables de diffuser dans la plante à température non permissive (tr-transport). Les mutants du second groupe (Ni 2519 et LS1) ne migrent pas dans la plante à température restrictive (ts-transport). L'étude montre que les vRNP sont produits à température restrictive par les mutants tr-transport et non par les mutants ts-transport. En revanche ceux-ci produisent des vRNP à température permissive.

L'infection simultanée d'une plante avec les mutants Ni 118 et LS1 à température non permissive se traduit aussi par le transport à longue distance et la production de vRNP caractéristiques des 2 mutants (complémentation réciproque). Ces résultats suggèrent que les vRNP sont un nouveau groupe de particules de type informosome codées par le virus et qui jouent un rôle dans la migration de cellule à cellule et le transport du virus à plus longue distance (DorokHov et al., 1984). Plus récemment le rôle possible de la protéine $32 \mathrm{kd}$ de l'AIMV pour faciliter le transport du virus de cellule à cellule a été appuyé par la démonstration de sa localisation dans les parois cellulaires du tabac (GODEFROYColburn et al., 1986).

\section{Acquisition et transmission par les vecteurs}

Certains isolats de Potyvirus peuvent être acquis et transmis par les pucerons, selon le mode non persistant, seulement si la plante source est également infectée par une souche commune normalement transmise (KASSANIS, 1961). En fait, pour que ces isolats deviennent transmissibles, il suffit que les pucerons aient d'abord fait des piqûres d'épreuve sur une plante infectée par une souche transmissible du PVY (Kassanis \& Govier, $1971 a)$.

On a montré que les pucerons ne peuvent acquérir le PVY purifié au travers d'une membrane que si la préparation renferme un extrait de feuilles infectées par le PVY et pourtant débarrassé de toute particule virale. L'existence d'un facteur assistant (FA) nécessaire à la transmission aphidienne a donc été suspectée (KASSANIS \& Govier, 1971b). Par la suite, ce FA produit dans la plante infectée par le PVY a été purifié et ajouté à la préparation ; il permet la transmission du virus par les pucerons (Govier \& KASSANIS, 1974a, b). Le FA favoriserait l'attachement des particules aux sites spécifiques des stylets du puceron vecteur (GoviER et al.,
1977). Les FA du PVY et TVMV ont été purifiés : ce sont des protéines actives sous la forme dimère et d'une masse moléculaire voisine de $50 \mathrm{kd} \times 2$ (THORNBURY et al., 1985).

Le FA a été identifié sérologiquement à une protéine produite lors de la traduction in vitro de l'ARN de certains Potyvirus. Ceci suggère que le FA est codé au moins en partie par le virus (HELMANN et al., 1982; Thornbury \& Pirone, 1983).

Des études ont été faites sur la spécificité du FA pour la vection de différents potyvirus purifiés et acquis par les pucerons sur membrane. Certains FA ont une spécificité très étroite et n'assistent la vection que du seul virus homologue. D'autres, au contraire, ont une plus large gamme d'activité ; ainsi, le FA-PVY assiste la transmission de plusieurs virus des Solanacées (PVC, PAMV, KASSANIS \& GoviER, $1971 b$ ) mais également celle du TuMV (Crucifères) et du MDMV (Graminées) (Govier et al., 1977 ; SimONS, 1976; RACCAH et al., 1984). Inversement, un virus peut n'être transmis qu'en présence du FA homologue ou, au contraire, il peut être assisté par des FA différents.

Ainsi, le TuMV peut être assisté par les FA du PVY et du WMV (Cucurbitacées) alors que la transmission effective du PVY est assurée, à un niveau plus faible cependant, par les FA du BYMV (haricot) et du PRSV (Cucurbitacées) mais pas après acquisition préalable des FA du TuMV (Crucifères) ou du WMV (Cucurbitacées) (Sako \& OGATA, 1981 ; Pirone, 1981; RaCCAH et al., 1984).

L'étude des combinaisons entre 3 virus des Cucurbitacées a permis de mettre en évidence des différences quantitatives dans les degrés d'assistance entre FA et virus homologues ou hétérologues (LECOQ \& PITRAT, 1985).

Signalons, enfin, que les tentatives d'utilisation de plantes infectées par un potyvirus comme source de FA pour réussir la transmission par pucerons de virus éloignés non transmissibles (CMV, CaMV, TMV), ont échoué (Govier \& KASSANIS, 1974b. PIRONE, 1977).

La transmission du CaMV par les pucerons, selon le mode non persistant, nécessite aussi la présence d'un FA synthétisé dans les feuilles infectées. La transmission d'un isolat non transmissible peut être assurée par l'acquisition préalable ou simultanée du FA d'un isolat transmissible (LUNG \& PIRONE, 1974). La synthèse du FA qui est donc sous la dépendance de l'ADN viral, est dirigée par la région II de la molécule circulaire de l'ADN du CaMV (ARMour et al., 1983).

\section{Discussion}

Chez un hôte commun, la fonction défective d'un mutant artificiel ou d'un variant naturel peut être complémentée, dans certains cas, par la souche sauvage ou par un variant défectif pour une autre fonction. Ces complémentations peuvent porter sur plusieurs protéines codées par le génome viral et dont les fonctions sont connues : capside, protéine de diffusion dans la plante, facteur assistant pour l'acquisition et la transmission de certains virus selon le mode non persistant.

Des recombinaisons génétiques ont été envisagées pour expliquer l'apparition d'une «nouvelle» souche 
chez une plante co-infectée par 2 souches d'un virus à génome simple (TMV : SUKHOV, 1956 ; PVY : WATSON, 1960 ; PVX : Thomson, 1961b). Cette hypothèse n'a pu être vérifiée. En revanche, la même observation effectuée avec 2 souches du TSWV (BEST, 1968) pourrait s'expliquer par un réassortiment des molécules d'ARN de ce virus classé maintenant parmi les virus à génome fragmenté (Van DeN HURK et al., 1977). Une nouvelle souche issue de la combinaison de 2 souches parentales peut être aussi la conséquence de pseudorecombinaisons entre virus à génome divisé.

\section{INTERACTIONS ENTRE COMPOSANTS DES VIRUS À GÉNOME DIVISÉ}

\section{A. Généralités}

L'activité infectieuse d'un nombre important de virus végétaux ne s'exprime, dans la plante ou dans les protoplastes, que par la combinaison de plusieurs espèces de molécules d'ARN distinctes par leurs masses moléculaires et qui codent pour des composants essentiels pour la réplication.

Associés à ces ARN génomiques, on rencorttre fréquemment des ARN sub-génomiques de plus petite taille. S'ils sont absents de l'inoculum, ils réapparaîtront dans la descendance. On connaît actuellement près de 50 virus végétaux à génome divisé bi- ou tri-partite. Ces virus appartiennent à au moins 12 groupes dont 8 sont à particules parasphériques. Les virus à génome divisé ont fait l'objet de nombreuses mises au point (Van VLOTEN-DOTING \& JASPARS, 1977 ; BRUENING, 1977; REIJNDERS, 1978; FRANCKI et al., 1987). Nous nous bornerons ici à la présentation des aspects biologiques principaux et récents de l'interaction entre ARN génomiques.

\section{B. Quelques exemples}

\section{Virus à génome bipartite}

Le TRV est le premier virus connu pour avoir un génome réparti dans 2 classes de particules : bâtonnets longs instables et bâtonnets courts stables. On a démontré que l'ARN des premiers code pour des composants essentiels de la réplication dont sont dépourvues les particules courtes. Réciproquement, l'ARN de ces dernières porte l'information pour la synthèse de la protéine capside qui fait défaut à l'ARN de grande taille.

On retrouve un systeme de complémentation comparable chez les Népovirus et les Comovirus puisque l'ARN-1, le plus grand, porte toutes les fonctions virales à l'exception du gène pour la capside. Celui-ci est porté par l'ARN-2 qui comporte également des informations indispensables au mouvement $d u$ virus dans la plante (RESELMAN et al., 1982).

\section{Virus à génome tripartite}

Le génome de l'AIMV est réparti dans 3 classes de nucléoprotéines (lourde - moyenne - légère). L'associa- tion de ces 3 types de particules est infectieuse mais curieusement l'association des ARN correspondants (ARN 1-2 et 3) ne l'est pas. Cette combinaison d'ARN devient infectieuse si on lui ajoute la protéine capside ou l'ARN-4.

L'inoculation chez le tabac d'une combinaison des ARN $(1+2+3)$ d'une souche d'AIMV et de l'ARN-4 d'une autre souche, entraîne la production de virions dont la capside est caractéristique de la souche ayant fourni les ARN $1+2+3$. On sait depuis, que le gène capside est porté par l'ARN-3 et que l'ARN-4 est une copie partielle de cet ARN génomique.

La protéine-capsidiale ou l'ARN-4 qui code pour cette protéine, permettrait l'amorce de la réplication des ARN génomiques et aurait une fonction de régulation sur la traduction de ces ARN (Van VLOTEN-Doting, 1978).

Le groupe des Ilarvirus présente une organisation génétique semblable à celle de l'AIMV (Van VLOTENDoting \& JASPars, 1977). Les Bromovirus et les Cucumovirus ont également un génome tripartite dont l'organisation présente de grandes analogies avec celui de l'AIMV. Ainsi, le gène-capside présent sur l'ARN-3 est redondant sur l'ARN-4. La différence est que le pouvoir infectieux des $3 \mathrm{ARN}$ génomiques des Bromoet Cucumovirus s'exprime même en absence de l'ARN-4 ou de la protéine capsidiale qui ne serait donc pas nécessaire ici pour que la réplication ait lieu (BANCROFT \& LANE, 1973 ; LoT et al., 1974).

\section{Interactions entre ARN appartenant à des souches différentes d'un même virus}

Dans la plupart des systèmes, la combinaison in vitro des ARN génomiques appartenant à des souches différentes d'une même "espèce " virale, a permis d'obtenir des pseudo-recombinants infectieux. Cependant, toutes les combinaisons entre souches ne sont pas toujours réalisables : TRV, Frost et al., 1967 ; CPMV, DE JAGER \& Van Kammen, 1970 ; TBRV, RANDles et al., 1977. Les résultats positifs ont d'abord confirmé la nature divisée des génomes, puis permis d'aborder la localisation sur l'un (et) ou l'autre ARN, du ou des "gènes" " responsables d'un caractère particulier à l'une ou l'autre des souches parentales. Les propriétés suivantes ont été étudiées: synthèse, propriétés physico-chimiques et sérologiques de la protéine capsidiale et des nucléoprotéines, symptômes chez certains hôtes, altération des chloroplastes, capacité de multiplication à température basse ou élevée, proportion relative des composants ARN ou nucléoprotéiques, sensibilité à la cyclohéximide, synthèse de la protéine liée à l'extrémité $5^{\prime}$, transmissibilité par pucerons et nématodes, aptitude à la prémunition et - en liaison avec le $\S$ suivant - aptitude à assister un ARN satellite (Cucumovirus : MossoP \& Francki, 1979b; TBRV: Murant \& Mayo, 1982).

Soulignons que certaines caractéristiques, notamment en rapport avec la symptomatologie, apparaissent liées à la coopération de "gènes " situés sur 2 classes d'ARN génomiques. L'association de ces 2 classes, issues chacune d'une souche différente, peut entraîner l'apparition d'une «nouvelle " souche induisant un symptôme nouveau par rapport aux souches parentales (MARCHOUX et al., 1974). 


\section{Interactions entre ARN appartenant à des virus appa- rentés}

Quelques pseudo-recombinants viables ont été obtenus par combinaison d'ARN génomiques provenant de 2 virus du même groupe. Il n'y a pas toujours réciprocité ; ainsi, chez les Bromovirus, l'ARN-3 du CCMV complémente les ARN $(1+2)$ du BMV (BANCROFT, 1972). Chez les Cucumovirus, l'ARN-3 du CMV complémente les ARN $(1+2)$ du TAV et inversement (HABILI \& FRANCKI, 1974) ; l'ARN-3 du CMV complémente aussi les ARN $(1+2)$ du PSV (MARCHOUX et al., 1975). On comprend que, dans ces cas, il y aura un phénomène de masquage génotypique partiel car les ARN $(1+2)$ d'un virus seront encapsidés dans la protéine capside de l'autre virus, puisque celle-ci est codée par l'ARN-3. En revanche, les ARN 1 ou $2 \mathrm{du}$ CMV ne sont pas échangeables avec leurs homologues du TAV et réciproquement (RAO \& FRANCKI, 1981). L'ARN-4 de plusieurs Ilarvirus active les ARN génomiques hétérologues (GONSALVES \& FULTON, 1977) et il y a équivalence entre la protéine capside de l'AIMV et celle de plusieurs Ilarvirus (Van VLOTEN-Doting, 1975; Gonsalves \& GaRnSEY, 1975). Ces protéines n'ont pourtant aucune homologie de séquences (ZUIDEMA \& JASPARS, 1985).

\section{E. Discussion}

Au plan évolutif, les virus à génome multipartite devraient être désavantagés puisque la probabilité de réussite de l'infection est théoriquement réduite par la nécessité de la coopération de 2 ou plusieurs particules. En fait, les virus à génome divisé sont transmis sans grande difficulté majeure par des vecteurs variés (pucerons, thrips, nématodes, champignons, graines, etc...) qui introduisent probablement les différentes particules simultanément dans la cellule.

On a donc pensé au contraire que les virus à génome multipartite avaient un avantage sélectif apporté par une nouvelle source de variation: les pseudorecombinaisons naturelles entre populations. En fait, ce phénomène ne semble pas avoir une grande importance dans la nature, peut-être en raison du fait qu'il nécessite une inoculation simultanée des composants complémentaires appartenant pour le moins à 2 populations. Dans un certain nombre de cas, la plante source renferme une population dominante; aussi l'acquisition de 2 ou plusieurs souches par le vecteur est plus probable par des prises de nourritures successives chez des hôtes infectés par des génotypes différents.

D'autre part, on sait que les facteurs qui apparaissent importants pour la survie des virus sont l'étendue de la gamme d'hôtes, l'adaptation à la transmission par les vecteurs, une grande vitesse d'invasion des tissus et une forte production de virions chez les hôtes, sans déclencher une réaction nécrotique létale. La variabilité de ces caractéristiques serait plus grande chez les virus à génome divisé (REIJNDERS, 1978). En fait, une comparaison globale de ces caractéristiques avec celles des virus à génome monopartite ne montre aucune supériorité objective des différents groupes de virus à génome multipartite (FULTON, 1980).

Il a été suggéré aussi que l'information génétique nécessaire à un virus pouvait être trop importante pour une seule particule dont la taille et la forme sont limitées par des contraintes géométriques et physicochimiques. Ceci serait particulièrement vrai pour les virus parasphériques qui représentent une grande partie des virus à génome divisé. D'autre part, les particules plus petites pourraient être avantagées pour la migration dans les tissus de la plante (Fulton, 1980).

Actuellement, il semble plutôt que l'avantage des virus à génome divisé se situerait au niveau des interactions avec l'hôte. La fragmentation du génome pourrait être une adaptation à la machinerie des cellules végétales qui ne traduit que le premier cistron en $5^{\prime}$ dans un message polycistronique. Certains ARN des virus à génome multipartite pourraient représenter des ARNm monocistroniques encapsidés séparément. Pour un virus il serait avantageux d'avoir un génome permettant la traduction simultanée de plusieurs gènes ou la traduction préférentielle dans le temps, de certains gènes qui dirigent la synthèse des protéines précoces indispensables à la réplication (CPMV, GolDBACH et al., 1980). Des sites préférentiels correspondant à des fonctions vitales pourraient également jouer un rôle. Ainsi, dans les protoplastes de tabac, la vitesse de synthèse des particules du TRV est différente selon qu'elles sont longues ou courtes. Presque toutes les particules longues sont associées avec les mitochondries et après les premières heures d'infection, les particules courtes sont en majorité libres dans le cytoplasme (HARRISON et al., 1976).

$\mathrm{Au}$ plan pratique, plusieurs laboratoires envisagent l'exploitation par génie génétique de la nature divisée du génome pour lutter contre les virus. On espère que l'expression globale des ARN génomiques pourrait être inhibée par le blocage de l'expression d'un des fragments de ce génome. Différents travaux indiquent que dans le phénomène de prémunition entre souches, la protéine capside de la souche prémunisante peut jouer un rôle décisif (MarchouX, 1987). La production de cette capside par la plante pourrait constituer une méthode efficace pour inhiber l'infection par le virus. L'insertion de l'ADNc du gène-capside du TMV dans le génome du tabac a protégé temporairement la plante de l'infection par ce virus (ABEL et al., 1986). La multiplication du virus est inhibée (Nelson et al., 1987). Les travaux sont actuellement étendus à certains virus à génome divisé (CMV, TBRV par exemple) qui ont l'avantage de produire et d'encapsider un ARN subgénomique portant le seul gène-capside.

\section{ASSISTANCE DES VIRUS ET ARN SATELLITES}

\section{A. Définitions}

Le terme virus satellite a été utilisé la première fois pour décrire le petit virus (STNV) associé naturellement au TNV et dont il dépend totalement pour sa multiplication et sa survie (KASSANIS, 1962).

Depuis, chez un nombre croissant de virus végétaux, des molécules d'ARN, généralement de petite taille, ont été mises en évidence. Elles sont dépendantes d'un virus assistant pour leur réplication et ne présentent aucune 
homologie ou, au plus, des homologies limitées de séquence avec le ou les ARN génomique(s) de celui-ci. Cette particularité oppose donc les satellites aux ARN défectifs, ARN génomiques fragmentés et ARN subgénomiques mais, les uns comme les autres, ont perdu une ou des fonctions essentielles pour leur survie autonome.

Virus satellites et ARN satellites ont des propriétés essentielles communes: la distinction repose sur le fait que les virus satellites sont encapsidés dans une protéine manteau dont ils portent l'information alors que les ARN satellites en sont dépourvus et sont encapsidés dans celle du virus assistant.

On connaît actuellement une quinzaine d'exemples d'ARN satellites décrits principalement chez des virus sphériques et à génome divisé, transmis par pucerons (Cucumovirus), par nématodes et par les semences (Népovirus). L'existence d'un ARN satellite associé au TMV a été montrée récemment (VALVERDE \& DODDS, 1986-1987).

Le groupe des virus satellites, longtemps limité au STNV, comporte probablement d'autres exemples notamment chez les graminées (LAPIERRE et al., 1976 ; BuzEN et al., 1984; Gingery \& Louie, 1985). Des mises au point récentes passent en revue ces différents systèmes (MURANT \& MAYO, 1982; FranCKI, 1985). Nous présenterons ici les propriétés générales des virus et ARN satellites en développant surtout les aspects biologiques de l'interaction avec le virus assistant et la plante-hôte.

\section{B. Spécificité de l'interaction satellite-virus assistant}

La multiplication et la survie de chaque satellite sont assurées par un virus spécifique. Selon les combinaisons, la spécificité de l'interaction satellite-souche de virus est plus ou moins étroite. Par exemple chez le CMV, les ARN satellites ou ARN-5 provenant de différents isolats peuvent être assistés à des niveaux équivalents par les isolats de virus homologues ou hétérologues (KAPER \& TOUSSIGNANT, 1977; JACQUEMOND \& LEROUX, 1982).

Dans d'autres systèmes la spécificité est plus étroite et un type de satellite est activé seulement ou davantage, par un groupe de souches apparentées par leurs propriétés biologiques (TNV, KasSANIS \& PHILIPS, 1970) ou sérologiques (TBRV, ArMV, MURANT \& MAYO, 1982).

Le plus souvent des virus différents, même apparentés, ne peuvent assister les satellites hétérologues. C'est le cas chez les Népovirus: EMV ou ToRSV vis-à-vis de l'ARN-sat du TRSV (SCHNEIDER, 1971); GCMV et ARN-sat du TBRV (MURANT \& MAYO, 1982), les Cucumovirus : CMV et PSV et les ARN-5 hétérologues (KAPER et al., 1978).

On connaît cependant quelques cas d'assistances hétérologues: ARN-5 du CMV par le TAV (Mossor \& FRANCKI, 1979b), ARN virusoïde du SNMV par le LTSV; ARN virusoïde du LTSV par le SoMV ou le SBMV (Jones \& MAYO, 1983 ; PALIwal, 1984).

\section{Influence du satellite sur la multiplication du virus assistant}

Les satellites sont inutiles pour la réplication des virus assistants mais ils peuvent interférer avec elle. Dans les systèmes où la multiplication du satellite est faible et qu'il reste minoritaire par rapport aux ARN génomiques du virus, le rendement en virions est peu ou pas altéré (TBRV, MURANT et al., 1973 ; TCV, AltenbaCH \& Howell, 1981 ; Simon \& Howell, 1986).

Dans les autres cas, le satellite peut atteindre des concentrations élevées et entraîne une diminution de la synthèse virale dans la plante. Cette baisse de rendement en virions est souvent accompagnée d'une diminution de l'activité infectieuse spécifique du virus et d'une réduction de la synthèse de tout ou partie des ARN génomiques (CMV: KAPER \& TOUSIGNANT, 1977; TAKANAMI, 1981 ; TBRV : Doz et al., 1977).

Chez le TNV, un même satellite n'inhibe pas avec la même intensité, différentes souches mais il n'y a pas de relation directe entre la concentration en satellite et le niveau de l'inhibition. Celle-ci dépend de la concentration relative satellite/virus dans l'inoculum et des espèces essayées (KAssanis \& PhILIPS, 1970).

En revanche, chez les Cucumovirus, l'inhibition de la multiplication des ARN génomiques est directement liée à la concentration en ARN-5. Ceci est un argument pour penser qu'ARN satellites et ARN génomiques sont en compétition pour un même système réplicatif (KAPER \& Tousignant, 1977; Mossop \& FranCKI, 1979b; JACQUEMOND \& Leroux, 1982). Cette hypothèse est confortée par l'étude des homologies de séquences terminales entre certains ARN satellites et ARN génomiques $(\S F)$. Des séquences complémentaires mises en évidence entre l'ARN-4 et l'ARN-5 pourraient indiquer que celui-ci régule les fonctions virales à la manière d'un ARN anti-sens (REZAIAN \& SYMONS, 1986).

\section{Effets de la présence d'un satellite sur les symptômes}

La présence d'un satellite dans la plante modifie l'expression de la maladie. L'effet varie en fonction du satellite, du virus assistant et de la plante hôte (KAPER \& Tousignant, 1984).

Chez un certain nombre de Népovirus, l'association du satellite modifie très peu l'aspect des symptômes systémiques produit par le virus assistant lorsqu'il est seul. Ce phénomène pourrait être lié au faible taux de multiplication de ces satellites. En revanche, chez les hôtes hypersensibles, le nombre et (ou) la taille des lésions locales sont diminués et leur forme est parfois modifiée: haricot, chénopode, Vigna... (KASSANIS, 1962 ; SCHNEIDER et al., 1972a; MURANT et al., 1973).

En présence de son satellite le LTSV produit des lésions nécrotiques et non plus chlorotiques (JONES \& MAYO, 1983 ; JoNEs et al., 1983). D'autres satellites ont pour effet de diminuer la gravité des symptômes observés chez un ou plusieurs hôtes systémiques (autres Népovirus dont le CYMV : PIAzzolla et al., 1986; TBSV : Hillman et al., 1985).

C'est également le cas des isolats d'ARN-5 du CMV qui diminuent l'intensité de la mosaïque observée chez différentes plantes sensibles (tabac, piment, maïs, ...) infectées par le virus seul. Chez la tomate, on distingue 2 types de satellites: les ARN-5 de type R qui atténuent très fortement les symptômes de marbrure et filiformisme produits par les ARN génomiques seuls (WATERWORTH et al., 1979; MOSSOP \& FRANCKI, $1979 b$ ) ; les ARN-5 de type D, au contraire, associés à 
différentes souches de CMV qui induisent une nécrose létale chez la tomate (KAPER \& WATERWORTH, 1977 ; WATERWORTH et al., 1978 ; JACQUEMOND \& LOT, 1981). Un ARN-5 nécrogène sur tomate a la particularité supplémentaire d'augmenter la gravité de la mosaïque chez le tabac (TAKANAMI, 1981).

Un syndrome nouveau: la feuille blanche de la tomate est également associé à un ARN-5 particulier (GONSALVES et al., 1982).

Le symptôme de chlorose jaune brillante chez le Vigna produite par une souche particulière de CMV n'est également obtenu qu'en présence d'un ARN-5 original (CARRINGTON et al., 1983).

D'autres exemples d'augmentation de la gravité des symptômes produits par le virus assistant, en présence de satellites sont connus: ArMV chez chénopode (MuRANT \& MaYo, 1982), TCV sur tulipe (AltenBACH \& Howell, 1981), VTMV sur Nicotiana clevelandii (FRANCKI et al., 1986), BNYVV sur chénopode (Kuszala et al., 1986). L'association du satellite avec l'ArMV semble entraîner le développement d'une maladie nouvelle dite " tête d'ortie » chez le houblon (DAvIS \& CLARK, 1983).

Il est intéressant de signaler aussi que la présence d'un satellite entraîne une diminution supplémentaire de la production de semence chez le soja infecté par le TRSV (SCHNEIDER et al., 1972b).

\section{E. Replication des satellites}

Les satellites ne possèdent pas l'information pour assurer leur réplication. On dit, à tort, qu'ils sont de trop petite taille car les viroïdes qui sont de la taille des plus petits ARN satellites sont, eux, aptes à une autoréplication assurée par les polymérases cellulaires.

Les satellites se multiplient probablement en empruntant le système de réplication du virus assistant. Ils ont de grandes capacités de survie leur permettant d'attendre la prise en charge, par le virus assistant, dans la cellule (JACQUEMOND \& LOT, 1982).

Une dose minimale de satellite est nécessaire dans l'inoculum pour qu'une multiplication appréciable soit assurée en présence du génome viral, par exemple $5 \cdot 10^{-4} \mu \mathrm{g} / \mathrm{ml} \mathrm{d}$ 'ARN-5 du CMV (Mossop \& FRANCKI, $1979 b$; JACQUEMOND \& LEROUX, 1982). La quantité d'ARN-satellites produite est fonction de l'isolat, du satellite et de la souche du virus assistant. Le rôle de l'espèce-hôte sur la quantité de satellites est déterminant. Ainsi chez les hôtes du CMV, la concentration en ARN-5 qui est faible chez la courgette, augmente considérablement quand la souche est repiquée sur les solanacées, l'épinard, etc... (KAPER \& ToUSIGNANT, 1977 ; JACQUEMOND \& LEROUX, 1982).

Si 2 satellites sont mis en présence ils entrent en compétition pour leur multiplication par le virus assistant (KASSANIS \& White, 1972). L'étude de l'interférence entre $A R N-5$ nécrogène et $A R N-5$ non nécrogène du CMV a donné des résultats intéressants. En effet, la contamination de jeunes tomates par une souche contenant l'ARN-5 non nécrogène les protège vis-à-vis d'une infection ultérieure par un isolat inducteur de nécrose (JACQUEMOND, 1982).

L'ARN-5 forme, comme les ARN génomiques, une structure bicaténaire au cours de sa réplication. Or
l'ARN-5 bicaténaire (bc) peut représenter jusqu'à 90 p. 100 du total des formes bc dans les plantes favorables à sa réplication. De plus, la quantité totale d'ARN bicaténaire est 2 à 5 fois supérieure à sa valeur en absence d'ARN-5 (DIAZ-RuIZ \& KAPER, 1977). L'ARN-5 bc est également nettement majoritaire dans les protoplastes infectés par le CMV «parasité 》 par son satellite (TAKANAMI et al., 1977).

L'accumulation de l'ARN-5 bc est corrélative des 2 effets rapportés précédemment: diminution de la concentration en CMV et atténuation des symptômes chez différents hôtes (excepté le couple tomate-ARN-5 de type D bien sûr) (HABILI \& KAPER, 1981). L'accumulation d'ARN-5 double brin pourrait indiquer que l'ARN-satellite exerce un rôle dans les mécanismes de régulation de la réplication du virus et de l'expression des symptômes.

En ce qui concerne la nécrose de la tomate liée à la présence d'un ARN-5 particulier, la question est également de savoir si elle est due à l'association ARN génomiques + ARN-5 de type D ou si l'ARN satellite exprime une fonction messagère propre. La même question se pose pour les autres ARN satellites.

\section{F. Propriétés messagères des ARN satellites}

\section{Taille et structure des ARN satellites}

La taille des ARN satellites, c'est-à-dire le nombre de nucléotides qui les constituent, conditionne probablement la quantité d'informations génétiques qu'ils possèdent.

Chez les Népovirus, l'ARN satellite du TBRV d'une masse moléculaire voisine de $400 \mathrm{kd}$ est composé de 1375 nucléotides (MEYER et al., 1984). Les ARN satellites du SLRV, du GBLV et du MLRV ont des tailles comparables (MAYO et al., 1982; GALLITELLI et al., 1981-82-85 ; FRITSCH et al., 1984). L'ARN du STNV est un peu plus petit et comporte 1239 nucléotides (YSEBAERT et al., 1980). La taille de l'ARN des autres virus satellites SPMV et SMWLMV sont comparables à celle du STNV (Buzen et al., 1984; Gingery \& LouIE, 1985). Les ARN satellites des Tombusvirus (TBSV, Hillman et al., 1984 ; TCV, Altenbach \& Howell, 1981) sont constitués d'une chaîne d'environ 500 nucléotides. Les plus petits ARN satellites ne comportent qu'environ 300 à 400 nucléotides; ils parasitent les Cucumovirus (CMV, PSV, références ci-dessous), certains Népovirus (TRSV, KIEFER et al., 1982 ; ArMV, Davies \& Clark, 1983 ; CYMV, Piazzola \& Rubino, 1984), le LTSV et d'autres Sobémovirus ou assimilés (JoNEs et al., 1983).

Compte tenu de la taille de certains de ces petits ARN satellites, on est tenté de les rapprocher des viroïdes, d'autant que les ARN satellites des Sobemovirus ou virus voisins présentent une structure circulaire et un nombre élevé d'appariement de bases qui les rapprochent de ceux-ci. Ces ARN satellites se distinguent nettement des viroïdes par 2 propriétés fondamentales : réplication non autonome, synthèse dans le cytoplasme. Ces molécules sont donc bien des ARN satellites mais ils ont une structure viroïdale (RANDLES et al., 1981; GOUld \& HATTA, 1981 ; JONES et al., 1983). 
La carte oligonucléotique et, parfois, la séquence nucléotidique complète de certains ARN satellites sont connues. La comparaison avec les ARN génomiques ou subgénomiques des virus assistants ne montre aucune (ou peu) d'homologie de séquences (TNV, SHOULDER et al., 1974, YSEBAERT et al., 1980 ; CMV, GOULD et al., 1978 ; TCV, AltenBaCH \& Howell, 1981; TRSV, REZAIAN \& JACKSON, 1981, BUZAYAN et al., 1986; BNYV, BOUZOUBAA et al., 1985; TBRV, RoBINSON, 1982, Meyer et al., 1984 ; CYMV, Piazzola \& RubiNO, 1984).

L'ARN satellite du TBSV présente d'importantes homologies de séquence avec certaines souches assistantes (Hillman et al., 1984-1985) mais pas avec d'autres souches (GAllitelli et al., 1985).

La totalité des ARN satellites ne présente pas d'homologies de séquences connues avec les ARN ou ADN de la plante-hôte. En revanche, il faut souligner les homologies entre ARN satellites et ARN génomiques $\mathrm{du}$ virus assistant; ainsi, les ARN satellites de longue taille ont des extrémités équivalentes ou identiques à celles de leur virus assistant et quelques séquences communes courtes (TBRV, MAYO et al., 1982, KOENIG \& FRITSCH, 1982). Les petits ARN satellites (Sobemovirus, Cucumovirus) n'ont pas les mêmes extrémités que les ARN de leur virus assistant, mais peuvent présenter des séquences communes (TCV, SIMON \& HowELL, 1986) ou complémentaires (CMV, REZAIAN \& SYMONS, 1986) avec leur virus assistant.

Lorsqu'on dispose de plusieurs isolats d'ARN satellite d'un même virus, il est intéressant de comparer leur patrimoine génétique. Ainsi, les séquences nucléotidiques d'au moins 10 isolats nécrogènes ou non, d'ARN-5 du CMV ont été établies. Elles comportent 333 à 342 nucléotides et présentent un haut degré d'homologie (RICHARds et al., 1978; Gordon \& SYMONS, 1983; Collmer et al., 1983 ; HidakA et al., 1979 ; Palukaitis \& ZAITLIN, 1984 ; AVILA-RINCON et al., 1986a,b). On relève une vingtaine de substitutions communes à plusieurs isolats et quelques insertions et délétions. Ces dernières présenteraient un intérêt majeur pour la capacité de codage mais il n'a pas été possible de relier ces différences ni celles déduites au niveau de la structure secondaire et des capacités codantes à des propriétés biologiques particulières, notamment l'induction de la nécrose ou de la feuille blanche chez la tomate (GARCIAArenal et al., 1987).

L'ARN-5 du PSV (Cucumovirus apparenté) est plus grand (393 nucléotides) et seulement 9 et 5 résidus aux extrémités $5^{\prime}$ et $3^{\prime}$ sont identiques à ceux de l'ARN-5 du CMV (KAPER et al., 1978 ; COLLMER et al., 1983).

Les ARN satellites de cinq isolats de TBRV ont été comparés par l'analyse des oligonucléotides. Les résultats font apparaitre beaucoup de similitudes entre les différents ARN satellites; les oligonucléotides les plus longs sont présents dans tous les ARN satellites. On trouve, cependant, des différences qui permettent de classer les ARN satellites en 2 groupes correspondants aux 2 sérotypes du TBRV (FRITSCH et al., 1984; HEMMER et al., 1987).

Malgré ces importants progrès, les mécanismes d'interactions moléculaires spécifiques entre souches de virus et satellites demeurent pratiquement inconnus.

\section{Propriétés messagères des ARN satellites}

Un certain nombre d'ARN satellites ont montré une activité messagère dans plusieurs systèmes acellulaires de traduction in vitro. Le seul produit de traduction de l'ARN du STNV est un polypeptide identique à sa protéine capside (LEUNG et al., 1976). On sait que celle-ci est différente de celle du virus, aussi, on peut affirmer que la dépendance du STNV et des autres satellites porte sur d'autres fonctions que la synthèse d'une protéine capside par le virus assistant.

Chez les Népovirus, les ARN satellites de grande taille: TBRV, MLRV et SLRV codent respectivement pour un polypeptide dont la masse moléculaire est voisine de 48,45 et $40 \mathrm{kd}$. Ces polypeptides sont également synthétisés dans des protoplastes infectés par le virus et son satellite. Ils pourraient être impliqués dans les processus de réplication (MEYER et al., 1984; MAYO et al., 1982 ; FRITSCH et al., 1984). Les ARN-3 et 4 du BNYVV mais dont la nature de satellites est discutée, notamment chez la betterave, dirigent la synthèse de polypeptides de $25 \mathrm{kd}$ et $31 \mathrm{kd}$ (RICHARDS et al., 1985).

Les ARN satellites plus petits: ArMV et TRSV (Népovirus), TCV (Tombusvirus) et Sobemovirus n'ont pas révélé de fonction messagère dans les mêmes conditions d'expériences (OWENS \& SCHNEIDER, 1977 ; AltenbaCh \& Howell, 1981 ; Kiberstis \& Zimmern, 1984).

En revanche, l'ARN-5 du CMV coderait selon les souches pour 2 polypeptides de masse moléculaire voisine de 5000 et $3000 \mathrm{~d}$ (OWENS \& KAPER, 1977 ; HidAKA et al., 1979) ou 7000 (YAMAGUCHI et al., 1982). Ces polypeptides n'ont pas été détectés, in vivo et leur fonction demeure inconnue.

Chez le TBRV, nous avons déjà signalé l'existence de 2 groupes de satellites dépendant spécifiquement de 2 groupes sérologiques de souches. L'analyse de la séquence des acides aminés des polypeptides respectifs révèle des différences qui confirment la séparation des satellites en 2 groupes (FRITSCH et al., 1984).

Le fait que les ARN satellites apparaissent messagers ou non indique que le mécanisme d'interaction satellitevirus-hôte n'est probablement pas unique.

\section{G. Discussion}

La liste des virus et ARN satellites associés aux virus végétaux s'allonge régulièrement et il n'est pas douteux que les progrès enregistrés dans les méthodes de détection permettront d'en découvrir des nouveaux.

Les satellites de virus sont maintenant reconnus comme des éléments contribuant au développement de certaines viroses et ils pourraient être liés à des maladies d'étiologie actuellement inconnue. Certains satellites, à l'image de leur virus assistant, ont une dissémination mondiale (ARN-5 et CMV).

Il apparaît déjà une diversité dans les systèmes satellites et l'on peut distinguer plusieurs groupes qui diffèrent par la taille, la structure et leur relation avec le virus-assistant et la plante-hôte. On devrait même ajouter la découverte récente d'un ARN satellite du virus satellite du TNV (MossoP cité par FRANCKI, 1985). En raison de leur petite taille les ARN satellites apparais- 
sent comme des modèles intéressants pour l'étude de la réplication, de la pathogenèse et surtout pour les expériences de manipulations génétiques par l'intermédiaire d'ADNc.

Plusieurs laboratoires en France et à l'étranger ont engagé des travaux dans ce sens. Des ADNc de certains ARN-5 du CMV ont été synthétisés, clonés et séquencés. Leurs transcrits dirigent in vitro la synthèse de 2 polypeptides similaires à ceux obtenus par traduction directe de l'ARN-5 (AvILA-RICON et al., 1986b). Chez la tomate, l'inoculation, en présence du CMV, de copies des ARN-5 de type D (nécrogène) ou de type $R$ (non nécrogène) induit des symptômes caractéristiques de chacun d'eux (COLlmer \& KAPER, 1986; JACQUEMOND \& LAUQUIN comm. personnelle).

L'expression des copies du STNV a aussi été obtenue en présence du virus assistant chez le Vigna (Van EMMELO et al., 1987).

L'ADNc de l'ARN-5 du CMV a été introduit dans des cellules de tabacs qui ont été régénérés. Il y a production d'ARN-5 transcrit et l'inoculation d'une souche de virus sans satellite se traduit par des symptômes très faibles et par l'encapsidation d'ARN satellite par cette souche qui devient «parasitée » (BAULCOMBE et al., 1986).

L'objectif appliqué de ces travaux est de faire produire à la plante ce parasite naturel du virus afin de la protéger de façon héréditaire d'une infection ultérieure par le virus assistant. Il ne serait plus nécessaire d'effectuer des inoculations du CMV avec son satellite comme on l'expérimente actuellement pour prémunir les tomates ou les piments (TIEN \& CHANG, 1983 ; YosHIDA et al., 1985; QIU, 1985).

\section{CONCLUSION}

L'analyse des interactions positives entre 2 virus "complets» a montré qu'elles peuvent se traduire par une accentuation des symptômes et même être à l'origine de syndromes nouveaux très graves. L'association d'un virus à un autre peut également être utile à leur acquisition et à leur transmission par les insectes vecteurs. Ainsi, certains virus non transmissibles quand ils sont seuls dans la plante, sont transmis en présence d'un virus assistant. Celui-ci agirait par sa protéine manteau qui encapsiderait l'ARN du virus déficient. Chez les Potyvirus, l'inaptitude d'une souche ou d'un virus à être transmis peut être due à son incapacité à synthétiser un facteur assistant; celui-ci pourra lui être fourni par une souche ou un autre virus « complet ». On rejoint ici les cas de complémentations génétiques simples ou doubles étudiées chez les mutants artificiels ou chez certains variants naturels défectifs pour la synthèse de la capside, la maturation des particules ou l'aptitude à la diffusion dans la plante.

Les virus à génome divisé représentent un degré plus élevé de complémentation puisque les fonctions essentielles (notamment la réplication) sont remplies par l'association de plusieurs molécules d'ARN. Enfin, les ARN et virus satellites de virus sont eux totalement dépendants pour leur réplication des virus assistants. Toutes ces situations ont en commun l'intérêt d'aider à mieux connaître les fonctions codées par le génome viral. L'étude génétique et la traduction in vitro des ARN génomiques, subgénomiques et satellites ont permis de localiser, sur chacun d'eux, certaines fonctions spécifiques. En raison de leur petite taille, ces ARN apparaissent comme des modèles intéressants pour les études de biologie moléculaire (relations structures-fonctions) et de transfert d'information génétique.

L'étude expérimentale de la spécificité des interactions structurales (mélange phénotypique) et génétiques (facteur assistant de vection, protéine de transport, recombinaison entre ARN des virus à génome divisé, aptitude à assister un satellite) peut également présenter un intérêt taxonomique, car elle est très étroite (intraspécifique) ou, au contraire, étendue à des virus apparentés (inter-spécifique). Les phénomènes de synergie - pour la multiplication et la pathogenèse, la transencapsidation et l'assistance pour le transport - peuvent même survenir entre virus non apparentés.

La connaissance des interactions entre virus, variants défectifs, composants génomiques et satellites ont une grande importance pour l'agriculture car elles sont dans certains cas à l'origine de phénomènes défavorables aux plantes ; ce sont notamment le développement de maladies complexes, souvent graves (nécroses généralisées), la dissémination de virus normalement non transmissibles par les pucerons, l'infection et la diffusion du virus chez des plantes résistantes. La nature divisée du génome offre, pour certains virus, une possibilité supplémentaire de variation donc d'adaptation, par constitution de pseudo-recombinants.

Certains résultats indiquent que des mécanismes de recombinaisons entre segments génomiques pourraient s'opérer au cours de la réplication entre 2 molécules d'ARN du même type appartenant à 2 souches différentes du CPMV (DE JAGER \& BREEKLAND, 1979). Plus récemment, une recombinaison moléculaire a été mise en évidence entre 2 segments génomiques du BMV (BUJARSKI \& KaEsBerG, 1986). Cette capacité de recombinaison intragénomique entre souches d'un virus offre des possibilités supplémentaires d'adaptation des virus végétaux.

Les interactions obligées entre éléments viraux peuvent aussi avoir des conséquences favorables pour la plante infectée. C'est ainsi que les protéines capsidiales et les ARN satellites peuvent, dans certain cas, réduire la réplication virale, la gravité des symptômes et, en conséquence, être utilisés comme moyens de prémunition des plantes.

C'est ainsi qu'au niveau des plantes transgéniques portant le gène capside du TMV ou certains ARN satellites on observe une interférence avec la réplication des virus assistants. Si ces résultats se confirment, l'utilisation des plantes transgéniques résistantes pourrait ouvrir une nouvelle voie pour la lutte contre les virus des plantes cultivées.

Reçu le 24 juillet 1987 Accepté le 2 avril 1988.

ABRÉVIATIONS UTILISÉES POUR LES VIRUS ET LEUR APPARTENANCE À UN GROUPE
AlMV
Alfalfa mosaic virus
ArMV
Arabis mosaic virus
AlMV-group
Nepovirus 
Anthriscus yellows virus

BGMV Bean golden mosaic virus

BICMV Black cowpea mosaic virus

BMV Brome mosaic virus

BNYVV Beet necrotic yellow vein virus

BPMV Bean pod mottle virus

BSMV Barley stripe mosaic virus

BWYV Beet western yellows virus

BYDV Barley yellow dwarf virus

BYMV Bean yellow mosaic virus

CaMV Cauliflower mosaic virus

CCMV Cowpea chlorotic mottle virus

CGMMV Cucumber green mottle mosaic virus

CLSV Cucumber leaf spot virus

CMV Cucumber mosaic virus

CMotV Carrot mottle virus

CPMV Cowpea mosaic virus

CRLV Carrot red leaf virus

CSMV Cowpea severe mosaic virus

CV4 Cucumber virus 4

CYMV Chicory yellow mottle virus

DEMV Dolichos enation mosaic virus

EMV Eucharis mottle virus

GBLV Grapevine bulgarian latent virus

GCMV Grapevine chrome mosaic virus

LMV Lettuce mosaic virus

LSMV Lettuce speckled mottle virus

LTSV Lucerne transient streak virus

MCMV Maize chlorotic mottle virus

MDMV Maize dwarf mosaic virus

MLRV Myrobalan latent ringspot virus

MWLMV Maize white line mosaic virus

PAMV Potato aucuba mosaic virus

PEMV Pea enation mosaic virus

PLRV Potato leaf roll virus

\begin{tabular}{ll}
\multicolumn{1}{c}{ Geminivirus } & PMV \\
Potyvirus & PNRSV \\
Bromovirus & PRSV \\
Furovirus & PSV \\
Comovirus & PVC \\
Hordeivirus & PVX \\
Luteovirus & PVY \\
Luteovirus & PYFV \\
Potyvirus & RMV \\
Caulimovirus & RRSV \\
Bromovirus & SBMV \\
Tobamovirus & SCMV \\
- & SLRV \\
Cucumovirus & SMV \\
Comoirus & SNMV \\
Comovirus & SoMV \\
Luteovirus & STNV \\
Comovirus & TAV \\
Tobamovirus & TBRV \\
Nepovirus & TBSV \\
Tobamovirus & TCV \\
Nepovirus & TEV \\
Nepovirus & TMV \\
Nepovirus & TMotV \\
Potyvirus & TNV \\
- & ToRSV \\
Sobemovirus & TRSV \\
- & TRV \\
Potyvirus & TSWV \\
Nepovirus & TVMV \\
- & TuMV \\
Potyvirus & VTMV \\
PEMV-group & WMV \\
Luteovirus & ZYMV \\
&
\end{tabular}

Panicum mosaic virus

Prunus necrotic ringspot virus

Papaya ringspot virus

Potato spindle tuber viroid

Peanut stunt virus

Potato virus $\mathrm{C}$

Potato virus $\mathrm{X}$

Potato virus $\mathrm{Y}$

Parsnip yellow fleck virus

Rose mosaic virus

Raspberry ringspot virus

Southern bean mosaic virus

Subterranean clover mottle virus

Strawberry latent ringspot virus

Soybean mosaic virus

Solanum nodiflorum mottle virus

Sowbane mosaic virus

Satellite tobacco necrosis virus

Tomato aspermy virus

Tomato black ring virus

Tomato bushy stunt virus

Turnip crinkle virus

Tobacco etch virus

Tobacco mosaic virus

Tobacco mottle virus

Tobacco necrosis virus

Tomato ringspot virus

Tobacco ringspot virus

Tobacco rattle virus

Tomato spotted wilt virus

Tobacco vein mottling virus

Turnip mosaic virus

Velvet tobacco mottle virus

Watermelon mosaic virus

Zucchini yellow mosaic virus
Ilarvirus

Potyvirus

Viroïde

Cucumovirus

Potyvirus

Potexvirus

Potyvirus

Ilarvirus

Nepovirus

Sobemovirus

Sobemovirus?

Nepovirus

Potyvirus

Sobemovirus

Sobemovirus

Cucumovirus

Nepovirus

Tombusvirus

Tombusvirus?

Potyvirus

Tobamovirus

TNV-group

Nepovirus

Nepovirus

Tobravirus

TSWV-group

Potyvirus

Potyvirus

Sobemovirus

Potyvirus

Potyvirus

\section{RÉFÉRENCES BIBLIOGRAPHIQUES}

Aapola A. I. E., Rochow W. F., 1971. Relationships among three isolates of barley yellow dwarf virus. Virology, 46, 127-141.

Abel P. P., Nelson R. S., Barun D. E., Hoffmann N., Rogers S. G., Fraley R. T., Beachy R. N., 1986. Delay of disease development in transgenic plants that express the tobacco mosaic virus coat protein gene. Science, 232, 738-743.

Adams A. N., Hull R., 1972. Tobacco yellow vein, a virus dependent on assistor viruses for its transmission by aphids. Ann. appl. Biol., 71, 135-140.

Altenbach S. B., Howell S. H., 1981. Identification of a satellite RNA associated with turnip crinkle virus. Virology, 112, 25-33.

Altenbach S. B., Howell S. H., 1984. Nucleic acid species related to the satellite RNA of turnip crinkle virus in turnip plants and virus particles. Virology, 134, 72-77.

Armour S. L., Melcher U., Pirone T. P., Lyttle D. J., Essenberg R. C., 1983. Helper component for aphid transmission encoded by region II of cauliflower mosaic virus DNA. Virology, 129, 25-30.

Asselin A., 1984. A note on the induction of the streak disease in different tomato cultivars by tomato mosaic virus and potato virus $\mathrm{X}$. Phytoprotection, 65, 81-83.

Atabekov J. G., 1975. Host specificity of plant viruses. Annu. Rev. Phytopathol., 13, 127-145.

Atabekov J. G., Dorokhov Y. L., 1984. Plant virus-specific transport function and resistance of plants to viruses. Adv. Virus Res., 29, 313-364.

Atabekov J. G., Schaskolskaya N. D., Atabekova T. I., Sacharovskaya G. A., 1970. Reproduction of temperature-sensitive strains of TMV under restrictive conditions in the presence of temperature-resistant helper strain. Virology, 41, 397-407.

Atabekov J. G., Taliansky M. E., Drampyan A. H., Kaplan I. B., Tupka I. E., 1984. Systemic infection by a phloem-restricted virus in parenchyma cells in a mixed infection. Biol. Nauki, 10, 28-31.

Atabekova T. I., Taliansky M. E., Atabekov J. G., 1975. Specificity of protein-RNA and protein-protein interaction upon assembly of TMV in vivo and in vitro. Virology, 67, 1-13.
Avila-Rincon M. J., Collmer C. W., Kaper J. M., 1986a. In vitro translation of cucumoviral satellites. I. Purification and nucleotide sequence of cucumber mosaic virus-associated RNA-5 from cucumber mosaic virus strain S. Virology, 152, 446-454.

Avila-Rincon M. J., Collmer C. W., Kaper J. M., 1986b. In vitro translation of cucumoviral satellites. II. CARNA-5 from cucumber mosaic virus strain S and SP6 transcripts of cloned (S) CARNA-5 cDNA produce electrophoretically comigrating protein products. Virology, 152, 455-458.

Bancroft J. B., 1972. A virus made from parts of the genomes of brome mosaic and cowpea chlorotic mottle viruses. J. gen. Virol., 14 223-228.

Bancroft J. B., Lane L. C., 1973. Genetic analysis of cowpea chlorotic mottle and brome mosaic viruses. J. gen. Virol., 19, 381-389.

Barker H., 1987. Invasion of non-phloem tissue in Nicotiana clevelandii by potato leafroll luteovirus is enhanced in plants also infected with potato Y potyvirus. J. gen. Virol., 68, 1223-1227.

Barker H., Harrison B. D., 1977. The interaction between raspberry ringspot and tobacco rattle viruses in doubly infected protoplasts. $J$. gen. Virol., 35, 135-148.

Baulcombe D. C., Saunders G. R., Bevan M. V., Mayo M. A., Harrison B. D., 1986. Expression of biologically active viral satellite RNA from the nuclear genome of transformed plants. Nature, 321, 446-449.

Bem F., Murant A. F., 1980. Heracleum latent virus. $C M I / A A B$, Descriptions of Plant Viruses, $\mathrm{n}^{\circ} 228$.

Best R. J., 1968. Tomato spotted wilt virus. Adv. Virus Res., 13, $65-146$

Bouzoubaa S., Guilley H., Jonard G., Richards K., Putz C., 1985 Nucleotide sequence analysis of RNA-3 and RNA-4 of beet necrotic yellow vein virus, isolates F2 and G1. J. gen. Virol., 66, 1553-1564.

Bruening G., 1977. Plant covirus systems : two-component systems. In Comprehensive Virology, Eds. H. Fraenkel-Conrat, R. R. Wagner, New York \& London : Plenum, 11, 55-141.

Bujarski J. J., Kaesberg P., 1986. Genetic recombination between RNA components of a multipartite plant virus. Nature, 321, 528-531 
Buzayan J. M., Gerlach W. L., Bruening G., Keese P., Gould A. R., 1986. Nucleotide sequence of satellite tobacco ringspot virus RNA and its relationship to multimeric forms. Virology, 151, 186-189.

Buzen F. G., Niblett C. L., Hooper G. R., Hubbard J., Newman M. A., 1984. Further characterization of panicum mosaic virus and its associated satellite virus. Phytopathology, 74, 313-318.

Calvert L. A., Ghabrial S. A., 1983. Enhancement by soybean mosaic virus of bean pod mottle virus titer in doubly infected soybean. Phytopathology, 73, 992-997.

Carr R. J., Kim K. S., 1982. Ultrastructure of mixed plant virus infection : bean yellow mosaic virus with cowpea severe mosaic virus or cowpea mosaic virus in bean. Virology, 124, 338-348.

Carr R. J., Kim K. S., 1983. Evidence that bean golden mosaic virus invades non-phloem tissue in double infections with tobacco mosaic virus. J. gen. Virol., 64, 2489-2492.

Carrington C., Morris T. J., Dawson W. O., 1983. Comparisons of cucumoviruses and their satellites. Phytopathology, 73, 787 (abstr.).

Clark R. L., Hill J. H., Ellis M. D., 1980. Tomato scorch, a new virus disease of tomatoes. Phytopathology, 70, 131-134.

Close R. C., 1964. Some effects of other viruses and of temperature on the multiplication of potato virus X. Ann. appl. Biol., 53, 151-164.

Cockbain A. J., 1978. Bean yellow vein-banding virus. Rep. Rothamsted Exp. Stn., $1977: 221-222$

Collmer C. W., Kaper J. M., 1986. Infectious RNA transcripts from cloned cDNAS of cucumber mosaic viral satellites. Bioch. Biophys. Res. Comm., 135, 290-296.

Collmer C. W., Toussignant M. E., Kaper J. M., 1983. Cucumber mosaic virus-associated RNA-5. X. The complete nucleotide sequence of a CARNA-5 incapable of inducing tomato necrosis. Virology, 127, 230-234.

Davies D. L., Clark M. F., 1983. A satellite-like nucleic acid of arabis mosaic virus associated with hop nettlehead disease. Ann. appl. Biol., 103, 439-448.

Dawson J. R. O., Motoyoshi F., Watts J. W., Bancroft J. B., 1975. Production of RNA and coat protein of a wild type isolate and a temperature-sensitive mutant of cowpea chlorotic mottle virus in cowpea leaves and tobacco protoplasts. J. gen. Virol., 29, 99-107.

Dawson J. R. O., Watts J. W., 1979. Analysis of the products of mixed infection of tobacco protoplasts with two strains of cowpea chlorotic mottle virus. J. gen. Virol., 45, 133-137.

De Jager C. P., Breekland L., 1979. Evidence for intrastrand complementation in cowpea mosaic virus infection. Virology, 99, 312-318.

De Jager C. P., Van Kammen A., 1970. The relationship between the components of cowpea mosaic virus. III. Location of genetic information for two biological functions in the middle component of CPMV. Virology, 41, 281-287

Delecolle B., Gebre Selassie K., Marchoux G., 1984. Encapsidation hétérogène chez les Potyvirus : une approche par la méthode d'immunoélectromicroscopie. $26^{e}$ Col. S.F.P., Avignon. "Les colloques de l'I.N.R.A. », 26, 195-198.

Demski J. W., Jellum M. D., 1975. Single and double virus infection of soybean plant characteristics and chemical composition. Phytopathology, 65, 1154-1156.

Diaz-Ruiz J. R., Kaper J. M., 1977. Cucumber mosaic virusassociated RNA-5. III. Little nucleotide sequence homology between CARNA-5 and helper RNA. Virology, 80, 204-213.

Dodds J. A., Hamilton R. I., 1972. The influence of barley stripe mosaic virus on the replication of tobacco mosaic virus in Hordeum vulgare L. Virology, 50, 404-411.

Dodds J. A., Hamilton R. I., 1974. Masking of the RNA genome of tobacco mosaic virus by the protein of barley stripe mosaic virus in doubly infected barley. Virology, 59, 418-427.

Dodds J. A., Hamilton R. I., 1976. Structural interactions between viruses as a consequence of mixed infections. Adv. Virus Res., 20, 33-86.

Dorokhov Y. L., Alexandrova N. M., Miroshnichenko N. A., Atabekov J. G., 1983. Isolation and analysis of virus-specific ribonucleoprotein of tobacco mosaic virus-infected tobacco. Virology, 127, 237-252

Dorokhov Y. L., Alexandrova N. M., Miroshnichenko N. A., Atabekov J. G., 1984. The informosome-like virus-specific ribonucleoprotein (vRNP) may be involved in the transport of tobacco mosaic virus infection. Virology, 137, 127-134.
Doz B., Dunez J., Bove J. M., 1977. Le RNA satellite (RNA-3) du virus des anneaux noirs de la tomate est encapsidé avec l'un des deux RNA majeurs (RNA-2) dans une nouvelle nucléoprotéine. C. $R$. Acad. Sci. Paris, ser. D, 285, 1573-1576.

Elnagar S., Murant A. F., 1976a. Relations of the semi-persistent viruses, parsnip yellow fleck and anthriscus yellows, with their vector Cavariella aegopodii. Ann. appl. Biol., 84, 169-181.

Elnagar S., Murant A. F., 1976h. The role of the helper virus, anthriscus yellows in the transmission of parsnip yellow fleck virus by the aphid, Cavariella aegopodii. Ann. appl. Biol., 84, 169-181.

Elnagar S., Murant A. F., 1978. Aphid-injection experiments with carrot mottle virus and its helper virus, carrot red leaf. Ann. appl. Biol., 89, 245-250.

Falk B., Duffus J. E., Morris T. J., 1979. Transmission, host range, and serological properties of the viruses that cause lettuce speckles disease. Phytopathology, 69, 612-617.

Francki R. I. B., 1985. Plant virus satellites. Annu. Rev. Microbiol., 39, 151-174.

Francki R. I. B., Grivell C. J., Gibbs K. S., 1986. Isolation of velvet tobacco mottle virus capable of replication with and without a viroid-like RNA. Virology, 148, 381-384.

Francki R. I. B., Zaitlin M., Palukaitis P., 1986. In vivo encapsidation of potato spindle tuber viroid by velvet tobacco mottle virus particles. Virology, 155, 469-473.

Francki R. I. B., Milne R. G., Hatta T., 1987. Atlas of Plant Viruses. vol. 1 and 2. CRC. PRESS., 222-224 p.

Fraser R. S. S., Loughlin S. A. R., 1980. Resistance to tobacco mosaic virus in tomato : effects of Tm-1 gene on virus multiplication. J. gen Virol., 48, 87-96.

Fritsch C., Koenig I., Murant A. F., Raschke J. H., Mayo M. A., 1984 Comparisons among satellite RNA species from five isolates of tomato black ring virus and one isolate of myrobalan latent ringspot virus. J. gen. Virol., 65, 289-294.

Frost R. R., Harrison B. D., Woods R. D., 1967. Apparent symbiotic interaction between particles of tobacco rattle virus. J. gen. Virol., 1 , $57-70$.

Fujisawa I., Hayashi T., Matsui C., 1967. Electron microscopy of mixed infections with two plant viruses. I. Intracellular interactions between tobacco mosaic virus and tobacco etch virus. Virology, 33, 70-76.

Fulton R. W., 1980. Biological significance of multicomponent viruses. Annu. Rev. Phytopathol., 18, 131-146.

Gallitelli D., Piazzolla P., Savino V., Quacquarelli A., Martelli G. P., 1981. A comparison of myrobalan latent ringspot virus with other nepoviruses. J. gen. Virol., 53, 57-65.

Gallitelli D., Savino V., Martelli G. P., 1982. The middle component of strawberry latent ringspot virus. J. gen. Virol., 59, 169-172.

Gallitelli D., Hull R., Koenig R., 1985. Relationships among viruses in the Tombusvirus group : nucleic acid hybridization studies. J. gen Virol., 66, 1523-1531.

Garcia-Arenal F., Zaitlin M., Palukaitis P., 1987. Nucleotide sequence analysis of six satellites of RNAs of cucumber mosaic virus : primary sequence and secondary structure alterations do not correlate with differences in pathogenicity. Virology, 158, 339-347.

Gill C. C., Chong J., 1981. Vascular cell alteration and predisposed xylem infection in oats by inoculation with paired barley yellow dwarf viruses. Virology, 114, 405-413.

Gingery R. E., Louie R., 1985. A satellite-like virus particle associated with maize white line mosaic virus. Phytopathology, 75, 870-873.

Godefroy-Colburn T., Gagey M. J., Berna A., Stussi-Garraud C., 1986. A non-structural protein of alfalfa mosaic virus in the walls of infected tobacco cells. J. gen. virol., 67, 2233-2239.

Goldbach R., Rezelman G., Van Kammen A., 1980. Independent replication and expression of B-component RNA of cowpea mosaic virus. Nature, 286, 297-300.

Gonsalves D., Fulton R. W., 1977. Activation of prunus necrotic ringspot virus and rose mosaic virus by RNA-4 components of some ilarviruses. Virology, 81, 398-407.

Gonsalves D., Garnsey S. M., 1975. Infectivity of heterologous RNA-protein mixtures from alfalfa mosaic, citrus leaf rugose, citrus variegation and tobacco streak viruses. Virology, 67, 319-326. 
Gonsalves D., Provvidenti R., Edwards M. C., 1982. Tomato white leaf : the relation of an apparent satellite RNA and cucumber mosaic virus. Phytopathology, 72, 1533-1538.

Goodman R. M., Ross A. F., 1974a. Enhancement of potato virus X synthesis in doubly infected tobacco occurs in doubly infected cells. Virology, 58, 16-24.

Goodman R. M., Ross A. F., 1974 b. Enhancement by potato virus Y of potato virus $\mathrm{X}$ synthesis in doubly infected tobacco depends on the timing of invasion by the viruses. Virology, 58, 263-271.

Goodman R. M., Ross A. F., 1974c. Independent assembly of virions in tobacco doubly infected by potato virus $\mathrm{X}$ and potato virus $\mathrm{Y}$ or tobacco mosaic virus. Virology, 59, 314-318

Gordon K. H. J., Symons R. H., 1983. Satellite RNA of cucumber mosaic virus forms a secondary structure with partial 3'-terminal homology to genomal RNAs. Nucleic Acid Res., 11, 947-960.

Gould A. R., Hatta T., 1981. Studies on encapsidated viroid-like RNA. III. Comparative studies on RNAs isolated from velvet tobacco mottle virus and Solanum nodiflorum mottle virus. Virology, 109, 137-147.

Gould A. R., Palukaitis P., Simons R. H., Mossop D. W., 1978. Characterization of a satellite RNA associated with cucumber mosaic virus. Virology, 84, 443-455.

Govier D. A., Kassanis B., 1974a. Evidence that a component other than the virus particle is needed for aphid transmission of potato virus Y. Virology, 57, 285-286.

Govier D. A., Kassanis B., 1974b. A virus-induced component of plant sap needed when aphids acquire potato virus $\mathrm{Y}$ from purified preparations. Virology, 61, 420-426.

Govier D. A., Kassanis B., Pirone T. P., 1977. Partial purification and characterization of the potato virus $\mathrm{Y}$ helper component. Virology 78, 306-314.

Habili N., Francki R. I. B., 1974. Comparative studies on tomato aspermy and cucumber mosaic viruses. III. Further studies on relationships and construction of a virus from parts of the two viral genomes. Virology, 61, 443-449.

Habili N., Kaper J. M., 1981. Cucumber mosaic virus-associated RNA-5. VII. Double-stranded form accumulation and disease attenuation in tobacco. Virology, 112, 250-261.

Halstead B. E., Gill C. C., 1971. Effect of inoculation of oats with paired combinations of barley yellow dwarf virus isolates. Can. J. Bot., 49, 577-581.

Hamilton R. I., Dodds J. A., 1970. Infection of barley by tobacco mosaic virus in single and mixed infection. Virology, 42, 266-268.

Hamilton R. I., Nichols C., 1977. The influence of bromegrass mosaic virus on the replication of tobacco mosaic virus in Hordeum vulgare Phytopathology, 67, 484-489

Harrison B. D., Kubo S., Robinson D. J., Hutcheson A. M., 1976. The multiplication cycle of tobacco rattle virus in tobacco mesophyll protoplasts. J. gen. Virol., 33, 237-248.

Harrison B. D., Hutcheson A. M., Barker H., 1977. Association between the particles of raspberry ringspot and tobacco rattle viruses in.doubly infected Nicotiana benthamiana cells and protoplasts. J. gen. Virol., 36, 535-539.

Hellman G. M., Thornbury D. W., Hiebert E., Shaw J. G., Pirone T. P., Rhoads R. E., 1982. Cell-free translation of tobacco vein mottling virus RNA. II. Immunoprecipitation of products by antisera to cylindrical inclusion, nuclear inclusion, and helper component proteins. Virology, 124, 434-444.

Hemmer O., Meyer M., Greif C., Fritsch C., 1987. Comparison of the nucleotide sequences of five tomato black ring virus satellite RNAs. $J$. gen. Virol., 68, 1823-1833.

Hidaka S., Shimotohno K., Miura K., Takanami Y., Kubo S., 1979 Nucleotide sequence near the 5 -terminal of cucumber mosaic virus RNA-5 segment. Febs Letters, 98, 115-118.

Hillman B. I., Morris T. J., Schlegel D. E., 1984. Characterization of low molecular weight RNA species of members of the tombusvirus group. Phytopathology, 74, 807 (abstract).

Hillman B. I., Morris T. J., Schlegel D. E., 1985. Effects of lowmolecular weight RNA and temperature on tomato bushy stunt virus symptom expression. Phytopathology, 75, 361-365.

Honda Y., Matsui C., 1968. Electron microscopy of intracellular modifications of tobacco by mixed infections with cucumber mosaic and tobacco mosaic viruses. Phytopathology, 58, 1230-1235.
Honda Y., Matsui C., 1971. Distribution of tobacco mosaic virus in etiolated tobacco leaf cells infected with two viruses. Phytopathology 61, 759-762.

Hull R., Adams A. N., 1968. Groundnut rosette and its assistor virus. Ann. appl. Biol., 62, 139-145.

Jacquemond M., 1982. Phénomènes d'interférences entre les deux types d'ARN satellite du virus de la mosaïque du concombre. Protection des tomates vis-à-vis de la nécrose létale. C. R. Acad. Sc Paris, 294, 991-994.

Jacquemond M., Leroux J. P., 1982. L'ARN satellite du virus de la mosaïque du concombre. II. Etude de la relation virus-ARN satellite chez divers hôtes. Agronomie, 2, 55-62

Jacquemond M., Lot H., 1981. L'ARN satellite du virus de la mosaïque du concombre. I. Comparaison de l'aptitude à induire la nécrose de la tomate d'ARN satellites isolés de plusieurs souches du virus. Agronomie, 1, 927-932.

Jacquemond M., Lot H., 1982. L'ARN satellite du virus de la mosaïque du concombre. III. La propriété de survie in vivo. Agronomie, 2, 533-538.

Jones A. T., Mayo M. A., 1983. Interaction of lucerne transient streak virus and the viroid-like RNA-2 of Solanum nodiflorum mottle virus J. gen. Virol., 64, 1771-1774.

Jones A. T., Mayo M. A., Duncan G. H., 1983. Satellite-like properties of small circular RNA molecules in particles of lucerne transient streak virus. J. gen. Virol., 64, 1167-1173.

Kaper J. M., Tousignant M. E., 1977. Cucumber mosaic virusassociated RNA-5. I. Role of host plant and helper strain in determining amount of associated RNA-5 with virions. Virology, 80, 186-195.

Kaper J. M., Tousignant M. E., 1984. Virus satellites : parasitic NA capable of modulating disease expression. Endeavour, 8, 194-200.

Kaper J. M., Waterworth H. E., 1977. Cucumber mosaic virus associated RNA-5 causal agent for tomato necrosis. Science, 196, 429-431.

Kaper J. M., Tousignant M. E., Diaz-Ruiz J. R., Tolin S. A., 1978 Peanut stunt virus-associated RNA-5 : second tripartite genome virus with an associated satellite-like replicating RNA. Virology, 88, 166 170 .

Kassanis B., 1961. The transmission of potato aucuba mosaic virus by aphids from plants also infected by potato viruses A or Y. Virology, 13, 93-97.

Kassanis B., 1962. Properties and behaviour of a virus depending for its multiplication on another. J. gen. Microbiol, 27, 477-488.

Kassanis B., Govier D. A., 1971 a. New evidence on the mechanism of aphid transmission of potato $\mathrm{C}$ and potato aucuba mosaic viruses. $J$. gen. Virol., 10, 99-101.

Kassanis B., Govier D. A., 1971 b. The role of the helper virus in aphid transmission of potato aucuba mosaic virus and potato virus C. $J$. gen. Virol., 13, 221-228

Kassanis B., Bastow C., 1971, In vivo phenotypic mixing between two strains of tobacco mosaic virus. J. gen. Virol., 10, 95-98.

Kassanis B., Conti M., 1971. Defective strains and phenotyping mixing. J. gen. Virol., 13, 361-364.

Kassanis B., Phillips M. P., 1970. Serological relationship of strains of tobacco necrosis virus and their ability to activate strains of satellite virus. J. gen. Virol., 9, 119-126.

Kassanis B., White R. F., 1972. Interference between two satellite viruses of tobacco necrosis virus. J. gen. Virol., 17, 177-183.

Kieffer M. C., Daubert S. D., Schneider I. R., Bruening G., 1982. Multimeric forms of satellite of tobacco ringspot virus RNA. Virology, 121, 262-273.

Kiberstis P. A., Zimmern D., 1984. Translational strategy of Solanum nodiflorum mottle virus RNA : synthesis of a coat protein precursor in vitro and in vivo. Nucleic Acids. Res., 12, 933.

Koenig I., Fritsch C., 1982. A protein linked at the $5^{\prime}$ end of satellite and genomic tomato black ring virus RNAs. Study of in vitro translation after protease treatment. J. gen. Virol., 60, 343-353.

Kuszala M., Ziegler V., Bouzoubaa S., Richards K., Putz C., Guilley H., Jonard G., 1986. Beet necrotic yellow vein virus : different isolate are serologically similar but differ in RNA composition. Ann. appl. Biol., 109, 155-162. 
Lapierre H., Moreau J. P., Molin G., 1976. Une nouvelle maladie à virus du maïs : mosaique en anneaux foliaires du Bugey (France). Poljopr. Znan. Smotra, 39, 187-188.

Lecoq H., Pitrat M., 1985. Specificity of the helper-component mediated aphid transmission of three potyviruses infecting muskmelon. Phytopathology, 75, 890-893.

Leonard D. A., Zaitlin M., 1982. A temperature-sensitive mutant of tobacco mosaic virus defective in cell-to-cell generates an altered viral-coded protein. Virology, 117, 416-424.

Leung D. W., Gilbert C. W., Smith R. E., Sasavage N. L., Clark J. M., 1976. Translation of satellite tobacco necrosis virus ribonucleic acid by an in vitro system from wheat germ. Biochemistry, 15, 4943-4950.

Lesnaw J. A., Reichmann M. E., 1970. Identity of the 5'-terminal RNA nucleotide sequence of the satellite tobacco necrosis virus and its helper virus : possible role of the $5^{\prime}$-terminus in the recognition by virus-specific RNA replicase. Proc. Natl. Acad. Sci. USA, 66, 140-145.

Lot H., Marchoux G., Marrou J., Kaper J. M., West C. K., Van Vloten Doting L., Hull R., 1974. Evidence for three functional RNA species in several strains of cucumber mosaic virus. J. gen. Virol, 22, 81-93.

Lung M. C. Y., Pirone T. P., 1974. Acquisition factor required for aphid transmission of purified cauliflower mosaic virus. Virology, 60, 260-264.

Marchoux G., 1987. Interactions entre virus chez un hôte commun. I. Interférences négatives, antagonisme, prémunition, résistance induite. Agronomie, 7, 149-162.

Marchoux G., Douine L., Devergne J. C., 1975. Cucumoviruses: studies on construction of pseudo-recombinants from parts of their RNA genomes. Comm. 3re Int. Cong. Virol., Madrid, 90.

Marchoux G., Marrou J., Quiot J. B., 1974. Complémentation entre ARN de différentes souches du virus de la mosaïque du concombre. II. Mise en évidence d'une interaction entre deux ARN pour déterminer un type de symptôme. C. R. Acad. Sci., sér. D, 279, 1943-1945.

Mayee C. D., Sarkar S., 1982. An enhanced multiplication of potato virus $X$ is not related to a synergistic reaction between the potato viruses X and Y. Potato Res., 25, 343-346.

Mayo M. A., Barker H., Robinson D. J., 1982. Satellite RNA in particles of strawberry latent ringspot virus. J. gen. Virol., 63, 417-423.

Meyer M., Hemmer O., Fritsch C., 1984. Complete nucleotide sequence of a satellite RNA of tomato black ring virus. J. gen. Virol., 65, $1575-1583$.

Mossop D. W., Francki R. I. B., 1979a. The stability of satellite viral RNAs in vivo and in vitro. Virology, 94, 243-253.

Mossop D. W., Francki R. I. B., 1979b. Comparative studies on two satellite RNAs of cucumber mosaic virus. Virology, 95, 395-404.

Murant A. F., Mayo M. A., 1982. Satellites of plant viruses. Annu. Rev. Phytopathol., 20, 49-70.

Murant A. F., Mayo M. A., Harrison B. D., Goold R. A., 1973. Evidence for two functional RNA species and a « satellite " RNA in tomato black ring virus. J. gen. Virol., 19, 275-278.

Murant A. F., Waterhouse P. M., Raschke J. H., Robinson D. J., 1985. Carrot red leaf and mottle virus : observations on the composition of the particles in single and mixed infections. J. gen. Virol., 66, 1575-1579.

Nelson R. S., Abel P. P., Beachy R. N., 1987. Lesions and virus accumulation in inoculated transgenic tobacco plants expressing the coat protein gene of tobacco mosaic virus. Virology, 158, 126-133.

Nishiguchi M., Motoyoshi F., Oshima N., 1978. Behaviour of a temperature-sensitive strain of tobacco mosaic virus in tomato leaves and protoplasts. J. gen. Virol., 39, 53-61.

Ohno T., Takamatsu N., Meshi T., Okada Y., Nishiguchi M., Kiho Y., 1983. Single amino acid substitution in 30K protein of TMV defective in virus transport function. Virology, 131, 255-258.

Otsuki Y., Takebe I., 1978. Production of mixedly coated particles in tobacco mesophyll protoplasts doubly infected by strains of tobacco mosaic virus. Virology, 84, 162-171.

Owens R. A., Kaper J. M., 1977. Cucumber mosaic virus-associated RNA-5. II. In vitro translation in a wheat germ protein-synthesis system. Virology, 80, 196-203.

Owens R. A., Schneider I. R., 1977. Satellite of tobacco ringspot virus RNA lacks detectable mRNA activity. Virology, 80, 222-224.
Paliwal Y. C., 1984. Interaction of viroid-like RNA-2 of lucerne transient streak virus with southern bean mosaic virus. Can. J. Plant. Pathol., 6, 93-97.

Palukaitis P., Zaitlin M., 1984. Satellite RNAs of cucumber mosaic virus : characterization of two new satellites. Virology, 132, 426-435.

Peterson J. F., Brakke M. K., 1973. Genomic masking in mixed infections with brome mosaic and barley stripe mosaic viruses. Virology, 51, 174-182.

Piazzola P., Rubino L., 1984. Evidence that the low molecular weight RNA associated with chicory yellow mottle virus is a satellite. Phytopathol. Z., 111, 199-202.

Piazzolla P., Vovlas C., Rubino L., 1986. Symptom regulation induced by chicory yellow mottle virus satellite-like RNA. J. Phytopathology, 115, 124-129.

Pio-Ribeiro G., Wyatt S. D., Kuhn C. W., 1978. Cowpea stunt : a disease caused by a synergistic interaction of two viruses. Phytopatho$\log y, 68,1260-1265$

Pio-Ribeiro G., Kuhn C. W., Brantley B. B., 1980. Cowpea stunt : inheritance pattern of the necrotic synergistic reaction. Phytopathology, 70, 250-252.

Pirone T. P., 1977. Accessory factors in non-persistent virus transmission. K. F. Harris \& K. Maramorosch Eds. Aphids as Virus Vectors. Acad. Press, New York, 221-235.

Pirone T. P., 1981. Efficiency and selectivity of the helper-componentmediated aphid transmission of purified potyviruses. Phytopathology, 71, 922-924.

Poolpol P., Inouye T., 1986. Enhancement of cucumber mosaic virus multiplication by zucchini yellow mosaic virus in doubly infected cucumber plants. Ann. phytopathol. Soc. Jpn, 52, 22-30.

Qiu B. S., 1985. Satellite RNA of plant virus and its application in biological control of virus diseases. I. Construction of cucumber mosaic virus vaccine by adding the satellite RNA to its genome RNAs. Acta microbiol. sin., 25, 87-88.

Raccah B., Pirone T. P., Antignus Y., 1984. Characteristics and specificity of, and factors affecting, helper-component-mediated aphid transmission of several potyviruses. Phytoparasitica, 12, 207-208.

Randles J. W., Davies C., Hatta T., Gould A. R., Francki R. I. B., 1981. Studies on encapsidated viroid-like RNA. I. Characterization of velvet tobacco mottle virus. Virology, 108, 111-122.

Randles J. W., Harrison B. D., Murant A. F., Mayo M. A., 1977. Packaging and the biological activity of the two essential RNA species of tomato black ring virus. J. gen. Virol., 36, 187-193.

Rao A. L. N., Francki R. I. B., 1981. Comparative studies on tomato aspermy and cucumber mosaic viruses. VI. Partial compatibility of genome segments from the two viruses. Virology, 114, 573-575.

Reijnders L., 1978. The origin of multicomponent small ribonucleoprotein viruses. Adv. Virus Res., 23, 79-102.

Reselman G., Franssen H. J., Goldbach R. W., Ie S., Van Kammen A., 1982. Limits to the independence of bottom component RNA of cowpea mosaic virus. J. gen. Virol., 60, 335-342.

Rezaian M. A., Jackson A. O., 1981. Low-molecular-weight RNAs associated with tobacco ringspot virus are satellites. Virology, 114, 534-541.

Rezaian M. A., Symons R. H., 1986. Anti-sense regions in satellite RNA of cucumber mosaic virus form stable complexes with the viral coat protein gene. Nucleic Acids Research, 14, 3229-3239.

Richards K., Jonard G., Jacquemond M., Lot H., 1978. Nucleotide sequence of cucumber mosaic virus-associated RNA-5. Virology, 89, $395-408$.

Richards K., Jonard G., Guilley H., Ziegler V., Putz C., 1985. In vitro translation of beet necrotic yellow vein virus RNA and studies of sequence homology among the RNA species using cloned cDNA probes. J. gen. Virol., 66, 345-350.

Robinson D. J., 1982. Apparent lack of nucleotide sequence homology between the satellite and genome RNA species of tomato black ring virus. J. gen. Virol., 58, 453-456.

Rochow W. G., 1970. Barley yellow dwarf virus : phenotypic mixing and vector specificity. Science, 167, 875-878.

Rochow W. F., 1975. Barley yellow dwarf : dependent virus transmission by Rhopalosiphum maidis from mixed infections. Phytopathology, 65, 99-105. 
Rochow W. F., Gill C. C., 1978. Dependent virus transmission by Rhopalosiphum padi from mixed infections of various isolates of barley yellow dwarf virus. Phytopathology, 68, 451-456.

Sakai F., Dawson R. O., Watts J. W., 1983. Interference in infections of tobacco protoplasts with two bromovirus. J. gen. Virol., 64 , 1347-1354.

Sako N., Ogata K., 1981. Different helper factors associated with aphid transmission of some potyviruses. Virology, 112, 762-765.

Sarkar S., 1969. Evidence of phenotypic mixing between two strains of tobacco mosaic virus. Mol. gen. Genet., 105, 87-90.

Schneider I. R., 1971. Characteristics of a satellite-like virus of tobacco ringspot virus. Virology, 45, 108-122.

Schneider I. R., Hull R., Markham R., 1972a. Multidense satellite of tobacco ringspot virus : a regular series of components of different densities. Virology, 47, 320-330.

Schneider I. R., White R. M., Gooding G. V., 1972b. Two new isolates of the satellite of tobacco ringspot viruses. Virology, 50, 902-905.

Shalla T. A., Peterson L. J., Zaitlin M., 1982. Restricted movement of temperature sensitive virus in tobacco leaves is associated with a reduction in numbers of plasmodesmata. J. gen. Virol., 60, 355-358.

Shoulder A., Darby G., Minson T., 1974. RNA-RNA hybridization using 125 I-labelled RNA from tobacco necrosis virus and its satellites. Nature, 251, 733-735.

Siegel A., 1971. Pseudovirions of tobacco mosaic virus. Virology, 46, 50-59.

Simon A. E., Howell S., 1986. The virulent satellite RNA of turnip crinkle virus has a major domain homologous to the $3^{\prime}$ end of the helper virus genome. EMBO Journal, 5, 3423-3428.

Simons J. N., 1976. Aphid transmission of a nonaphid-transmissible strain of tobacco etch virus. Phytopathology, 66, 652-654.

Singh R. P., 1982. An unique interaction of spindle tuber viroid and virus $\mathrm{Y}$ in potatoes. Phytopathology, 72, 962 (Abstract).

Skotnicki A., Gibbs A., Shaw D. C., 1976. Mixed infection with two tobamoviruses: the formation of particles containing the coat protein messenger RNAs of either virus. Intervirology, 7, 328-337.

Skotnicki A., Scotti P. D., Gibbs A., 1977. Particles produced during a mixed infection by two tobamoviruses contain coat proteins of both viruses. Intervirology, 8, 60-64.

Smith K. M., 1946. Tobacco rosette: a complex virus disease. Parasitology, 37, 21-24.

Stouffer R. F., Ross A. F., 1961. Effect of infection by potato virus $Y$ on the concentration of potato virus $\mathrm{X}$ in tobacco plants. Phytopatho$\log y$, 51, 740-744.

Sukhov K. S., 1956. The problem of hereditary variation of phytopathogenic viruses. Publication Akad. Nauki SSSR, Moscow. $4 \mathrm{p}$

Sulzinski M. A., Zaitlin M., 1982. Tobacco mosaic virus replication in resistant and susceptible plants : in some resistant species virus is confined to a small number of initially infected cells. Virology, 121, 12-19.

Takanami Y., 1981. A striking change in symptoms on cucumber mosaic virus-infected tobacco plants induced by a satellite RNA Virology, 109, 120-126.

Takanami Y., Kubo S., Imaizumi S., 1977. Synthesis of single and double-stranded cucumber mosaic virus RNAs in tobacco mesophyll protoplasts. Virology, 80, 376-389.

Taliansky M. E., Atabekova T. I., Kaplan I. B., Morozov S. Y., Malyshenko S. I., Atabekov J. G., 1982a. A study of TMV ts-mutant Ni 2519. I - Complementation experiments. Virology, 118, 301-308.

Taliansky M. E., Malyshenko S. I., Pshennikova E. V., Kaplan I. B., Ulnova E. F., Atabekov J. G., 1982b. Plant virus-specific transport function. I - Virus genetic control required for systemic spread. Virology, 122, 318-326.

Taliansky M. E., Malyshenko S. I., Pshennikova E. S., Atabekov J. G., 1982c. Plant virus-specific transport function. II - A factor controlling virus host range. Virology, 122, 327-331

Thomson A. D., 1961a. Effect of tobacco mosaic virus and potato virus $\mathrm{Y}$ on infection by potato virus $\mathrm{X}$. Virology, 13, 262-264.

Thomson A. D., $1961 b$. Interaction between plant viruses. I - Appearance of new strains after mixed infection with potato virus $\mathrm{X}$ strains. Virology, 13, 507-514.
Thornbury D. W., Pirone T. P., 1983. Helper components of two potyviruses are serologically distinct. Virology, 125, 481-490.

Thornbury D. W., Hellmann G. M., Rhoads R. E., Pirone T. P., 1985 Purification and characterization of Potyvirus helper component. Virology, 144, 260-267.

Tien P., Chang X. H., 1983. Control of two seed-borne virus diseases in China by the use of protective inoculation. Seed Sci. Technol., 11, 969-972.

Uyemoto J. K., Claflin L. E., Wilson D. L., Raney R. J., 1981. Maize chlorotic mottle and maize dwarf mosaic viruses: effect of single and double inoculations on symptomatology and yield. Plant Dis., 65 , $39-41$

Valleau W. D., 1952. The evolution of susceptibility to tobacco mosaic virus in Nicotiana and the origin of the tobacco mosaic virus. Phytopathology, 42, 40-42.

Valverde R. A., Dodds J. A., 1986. Evidence for a satellite RNA associated naturally with the U5 strain and experimentally with the U1 strain of tobacco mosaic virus. J. gen. Virol., 67, 1875-1884

Valverde R. A., Dodds J. A., 1987. Some properties of isometric virus particles which contain the satellite RNA of tobacco mosaic virus. $J$. gen. Virol., 68, 965-972.

Van Emmelo J., Ameloot F., Fiers W., 1987. Expression in plants of the cloned satellite tobacco necrosis virus genome and of derived insertion mutants. Virology, 157, 480-487.

Van Den Hurk J., Tas P. W. L., Peters D., 1977. The ribonucleic acid of tomato spotted wilt virus. J. gen. Virol., 36, 81-91.

Van Vloten-Doting L., 1975. Coat protein is required for infectivity of tobacco streak virus: biological equivalence of the coat proteins of tobacco streak and alfalfa mosaic viruses. Virology, 65, 215-225.

Van Vloten-Doting L., 1978. Early events in the infection of tobacco with alfalfa mosaic virus. $J$. gen. Virol., 41, 649-652.

Van Vloten-Doting L., Jaspars E. M. J., 1977. Plant covirus systems : three component systems. In Comprehensive Virology, Eds. Fraenkel Conrad H., Wagner R. R., New York \& London Plenum, 11, 1-53.

Waterworth H. E., Tousignant M. E., Kaper J. M., 1978. A lethal disease of tomato experimentally induced by RNA-5 associated with cucumber mosaic virus isolated from commelina from El Salvador. Phytopathology, 68, 561-566.

Waterworth H. E., Kaper J. M., Tousignant M. E., 1979. CARNA-5, the small cucumber mosaic virus-dependent replicating RNA, regulates disease expression. Science, 204, 845-847.

Watson M. A., 1960. Evidence for interaction or genetic recombination between potato viruses $\mathrm{Y}$ and $\mathrm{C}$ in infected plants. Virology, 10, 211-232.

Watson M., Serjeant E. P., 1964. The effect of motley dwarf virus on yield of carrots and its transmission in the field by Cavariella aegopodit Scop. Ann. appl. Biol., 53, 77-93.

Watts J. W., Dawson J. R. O., 1980. Double infection of tobacco protoplasts with brome mosaic virus and cowpea chlorotic mottle virus. Virology, 105, 501-507.

Weber I., Stanarius A., Kegler H., Kleinhempel H., 1985. Interactions of cucumber leaf spot virus and cucumber green mottle mosaic virus during infection and spread in test plants. Arch. Phytopathol. Pflanzensch., 21, 347-351.

Wyatt S. D., Kuhn C. W., 1979. Replication and properties of cowpea chlorotic mottle virus in resistant cowpeas. Phytopathology, 69, 125-129.

Yamaguchi K., Hidaka S., Miura K., 1982. Relationship between structure of the $5^{\prime}$ noncoding region of viral mRNA and efficiency in the initiation step of protein synthesis in a eukaryotic system. Proc. Natl. Acad. Sci., USA, 79, 1012-1016.

Yoshida K., Goto T., Izuka N., 1985. Attenuated isolates of cucumber mosaic virus produced by satellite RNA and cross protection between attenuated isolates and virulent ones. Ann. phytopathol. Soc. Jpn, 51, 238-242

Ysebaert M., Van Emmelo J., Fiers W., 1980. Total nucleotide sequence of a nearly full-size DNA copy of satellite tobacco necrosis virus RNA. J. mol. Biol., 143, 273-287.

Zachos D., 1954. Sur un phénomène d'interférence entre le virus de la mosaïque du tabac et le virus $\mathrm{X}$ de la pomme de terre, dans le cas d'une maladie complexe de la tomate (streak). C. R. Acad. Sci. Paris, 238, 269-270.

Zink F. W., Duffus J. E., 1972. Association of beet western yellows and lettuce mosaic viruses with internal rib necrosis of lettuce Phytopathology, 62, 1141-1144.

Zuidema D., Jaspars E. M. J., 1985. Specificity of RNA and coat protein interaction in alfalfa mosaic virus and related viruses. Virolo$g y, 140,342-350$. 